\title{
Patronos e identidades en la Monarquía Hispánica en el período de la disputa del patronato de Santiago (1618-1630)*
}

\author{
Ofelia Rey Castelao ${ }^{1}$ \\ Universidade de Santiago de Compostela \\ ofelia.rey@usc.es
}

RESUMEN: En este artículo se trata la relación entre santidad, representación simbólica e identidad colectiva. Para analizar esa relación se estudia el período de cambio del patronato del Apóstol Santiago bajo Felipe III y Felipe IV (1618-1630) en favor de Teresa de Ávila. El análisis no se basa en los hechos de ese periodo, bien conocidos, sino en dos planos de observación: el territorial, planteando cómo se vivieron esos cambios en Portugal, en vísperas de su movimiento de separación de 1640, cuando ese reino creaba su propia identidad; el social, planteando si por debajo de las elites políticas y cortesanas implicadas e interesadas en esos cambios, los otros sectores sociales castellanos, en especial el campesinado, compartieron ese interés o si tenían algún sentido de la identidad.

Palabras Clave: patronato; identidad; onomástica; Castilla; Portugal.

Patron saints and identities in the Hispanic monarchy during the dispute regarding the Patronage of Saint James the Great (1618-1630)

ABSTRACT: This paper addresses the relationship between sanctity, symbolic representation and collective identity through a study of the period when the traditional patronage of Saint James the Great was replaced with a new patron saint, namely Teresa of Ávila - under Philip III and Philip IV (1618-1630). The analysis focuses on the territorial and social perspective rather than on the well-known events surrounding the dispute itself. The

* Esta investigación se ha realizado dentro del proyecto de investigación, «Orden, conflicto y resistencias en el Noroeste peninsular ibérico en la Edad Moderna», PGC2018-093841B-C31, financiado por la Agencia Estatal de Investigación y Fondos Feder (Unión Europea).

${ }^{1}$ ORCID iD: https://orcid.org/0000-0002-9720-8486

Copyright: (C) 2020 CSIC. Este es un artículo de acceso abierto distribuido bajo los términos de una licencia de uso y distribución Creative Commons Reconocimiento 4.0 Internacional (CC-BY 4.0) 
territorial dimension considers experience of these changes in Portugal, on the verge of its 1640 segregation when it was in the process of creating its own identity. The social angle considers whether, apart from the Castilian court and political elites who were engaged or had an interest in these changes, other social sectors in Castile, particularly the peasantry, shared in this interest or themselves had a sense of identity.

KeY WORDS: patron saint; identity; onomastics; Castile; Portugal.

CÓMO CITAR ESTE ARTÍCULO/CITATION: Rey Castelao, Ofelia, «Patronos e identidades en la monarquía hispánica en el período de la disputa del patronato de Santiago (1618-1630)», Hispania, 80/265 (Madrid, 2020): xxx-xxx. https://doi.org/10.3989/ hispania.2020.021.

\section{INTRODUCCIÓN}

Lo que planteamos en estas páginas es si los patronos de referencia general - «nacional» sería un anacronismo - sirvieron para generar identidad política o, dicho de otro modo, cuál era el papel que la santidad jugó en la representación simbólica y en la configuración de una identidad colectiva. En los últimos años la cuestión de las bases históricas de la identidad se ha analizado y revisado en una bibliografía numerosa, de desigual procedencia, que ha entrado en debates empleando casi siempre las mismas bases informativas, en especial, textos cronísticos, y que está escorada hacia la Edad Media, cuando se forjaron tanto las monarquías como sus patronos protectores, y hacia los patronos de regiones y ciudades. Para la Edad Moderna se ha aceptado sin más lo que vale para la Edad Media y para las entidades menores, esto es, la importancia de los santos patronos en la creación y conservación de identidad, como apoyo, complemento o sustitución de mejores fundamentos jurídicos o políticos. Ahora bien, si se cambian enfoques y fuentes, lo que puede ser válido para los patronos de regiones o de ciudades es menos claro que lo sea para los patronos generales de los que nos ocupamos aquí. Por otra parte, la Edad Moderna hereda un elenco de patronos ya asentados e idénticos mecanismos que los habían aupado a esa condición. A) El relato hagiográfico: como representación textual capaz de validar la santidad y de asegurar la veneración de una vida ejemplar; como construcción cultural e histórica que permitió a ciudades, órdenes, cofradías, etc., apropiarse del prestigio espiritual de un santo; y como creación de una tradición piadosa y ejercicio de formulación de identidad comunitaria y de cierta conciencia colectiva. B) Las reliquias: el componente emocional de su adoración y su eficiencia manipuladora, visibles en la liturgia, en textos narrativos y en la iconografía, daban sentido de comunidad y unificaban identidad y memoria, y hacían de las creencias algo material y tangible. C) Las fiestas y peregrinaciones, fomentadas por obispos que sustentaban su poder en los santos y aprovechadas por príncipes y reyes

Hispania, 2020, vol. LXXX, n. ${ }^{\circ}$ 266, septiembre-diciembre, págs. 783-816, ISSN: 0018-2141, e-ISSN: 1988-8368 https://doi.org/10.3989/hispania.2020.021 
para hacerse ver ${ }^{2}$. A este respecto, hay que tener en cuenta que la Edad Moderna contó con la imprenta, un medio de difusión de mensajes e imágenes sin duda muy útil a efectos de difundir un patronato, pero igual de útil para discutirlo, y que el culto a las reliquias y las peregrinaciones se pusieron en cuestión, lo que recomendaba recurrir a santos «naturales» y cercanos.

Así pues, consideramos que a los patronos generales se les supone una efectividad que quizá no tuvieran o que, al menos, resulta contradictoria o paradójica. A) No se mantuvo siempre al mismo patrono, sino que, continuando con una práctica medieval, se descartaban los que iban perdiendo eficacia ${ }^{3}$. B) No eran patronos de los reinos sino de las dinastías en el poder, aunque no siempre se puede comprobar esta diferencia. C) Había una tendencia habitual al doble patronato, masculino y femenino, combinando a un santo con la Virgen y más rara vez, con una santa. D) La pluralidad de patronos locales desvirtúa o relativiza la importancia de los generales, cuyo impacto popular es dudoso o, al menos, difícil de medir. Esto se podría aplicar a la monarquía hispánica, puzle de «patrias» de santos particulares de cada ciudad, provincia y reino, y un microcosmos de fidelidades que en los siglos XVI y XVII eran más fuertes que el sentimiento general, aunque sin entrar en conflicto ${ }^{4}$. El afecto al lugar propio solía ser más intenso que el colectivo y utilizaba recursos como la antigüedad de la población, la fidelidad al rey y a la iglesia, la sangre, el valor y la nobleza para reforzarse en el autogobierno, siendo el patrono un elemento simbólico de esa identidad local ${ }^{5}$. Esto no singulariza al caso español —en Francia sucedió algo parecido- ${ }^{6}$, pero sí lo hace la existencia de un imperio colonial: si Santiago Matamoros había servido en la península para engarzar particularismos — representaba a la España cristiana y permanente—- en América sirvió como soporte mesiánico para los conquistadores?. En palabras de Álvarez Junco,

2 Sobre estos tres elementos, ASHTON, 2000: 14. CLARKE y CLAYTON, 2011. CHAPMAN, 2013. RÄSÄNEN, HARTMANN y RICHARDS, 2016: 2. Para el interesante caso italiano, CALIÒ, DURANTI y MICHETTI, 2002. MERLUZZI, 2009.

3 WEBB, 1996.

${ }^{4}$ CHRISTIAN, 1991. KAGAN, 2010.

5 FLORISTÁN, 27 (2007): 59-82; 2004: 327. SERRANO MARTÍN, 2018: 75.

${ }^{6}$ Allí san Luis, canonizado en 1297, tuvo que esperar a Enrique IV y Luis XIV para ser reconocido como patrón; pero lo eran también el arcángel san Miguel, desde Carlomagno, y Juana de Arco. Cuando en 1577 se descubre la tumba de Saint Denis, supuesto apóstol de los galos enviado por San Juan, y se produce la «conversión» de Enrique IV en su oratorio, fue elevado a patrono. En este caso responde a una invitación lanzada al rey para someterse a un mundo que él no había instituido: el rey no era libre sino que estaba atado a la piedad de sus antepasados y de ello derivaba el bien del estado; los devotos de Saint Denis rechazaban ver a la sociedad concentrarse en la instancia política y significaba el resurgir de la Francia católica en su gesto inaugural. LE GALL, 2007.

7 CHOY, 1985. CARDAILLAC, 2002. CAMPOS MORENO y CARDAILLAC, 2007. DOMÍNGUEZ GARCÍA, 2008: 38-67. MORGAN, 2002. 
tomadas de Américo Castro, el Apóstol se convirtió en descabezador y símbolo de la España que mataba moros, los reyes de Castilla y León eran sus alféreces y su nombre se gritaba en las batallas, desde la de Clavijo hasta el combate de Pizarro contra Atahualpa ${ }^{8}$. Sin embargo, la cuestión es mucho más compleja. Sin ir más lejos, Santiago no cumple ninguna de las condiciones antes señaladas: no hubo un relato hagiográfico completo hasta las «vidas» del Apóstol escritas por Mauro Castellá Ferrer en 1610 y fray Hernando de Oxea en 1615; sus reliquias siempre fueron cuestionadas y más lo fue la peregrinación a un lugar tan extremo como Compostela.

En nuestra opinión, cualquier patronato general era una construcción política más que religiosa destinada a amalgamar a las elites o a determinadas elites en torno a un fin común. Pero esto podía ser contraproducente, por hartazgo, por las disputas entre partidarios de posibles patronos o por falta de verdadero control del discurso, de modo que hay que preguntarse si tenía alguna eficacia política o identitaria en las capas sociales situadas por debajo de las elites. Para hacerlo, abordamos el período del cambio de patronato por el que Felipe III (1618) y Felipe IV (1626) impusieron a Teresa de Ávila como compatrona al lado de Santiago. Esto nos permite plantear por qué, si el patronato de Santiago tenía una fuerza identitaria, la monarquía rompió una tradición asentada y lo hizo sin previo aviso. También permite observar hasta dónde llegaba la capacidad simbólica, religiosa y política del patronato de forma horizontal, viendo el alcance y la respuesta territorial al patronato, y de forma vertical, midiendo su dimensión social. Para lo primero, recurriremos a Portugal, utilizando crónicas y textos impresos de aquel período, por cuanto el cambio de patronato se produjo cuando ese reino, unido a la monarquía hispánica desde 1580, estaba intentado reforzar su propia identidad, y para lo segundo, observaremos de forma escalonada indicadores de aceptación o rechazo del patronato - advocaciones de cofradías, onomástica, etc.- - Dejamos fuera otros indicadores tratados anteriormente, como la presencia del Apóstol en las fiestas populares y en las fuentes literarias y, en especial, en el teatro barroco ${ }^{9}$. Antes, haremos una breve síntesis de los dos episodios del compatronato.

\section{Los dos patronatos de Teresa de Ávila}

En 1617 las Cortes de Castilla proclamaron compatrona a Teresa de Ávila, recién beatificada, y en 1618 Felipe III hizo efectiva esa designación. Se alteraba así un dominio que tenía su origen mítico en la batalla de Clavijo de 834, ganada a los musulmanes por Ramiro I, y el real, en una construcción política

\footnotetext{
8 ÁLVAREZ JUNCO y DE LA FUENTE, 2017: 26.

9 REY CASTELAO 1994: 185-196; 2018: 379-399; 2019, 475-492.
} 
frente al Islam, apoyada en la imagen del Santiago caballero - con un fuerte componente identitario-, que se había mantenido durante la Edad Media ${ }^{10}$. El patronato fue refrendado por los Reyes Católicos en 1486, al encomendarse al Apóstol en Compostela para emprender la conquista de Granada y, sobre todo, al confirmar los privilegios reales de la catedral compostelana, incluido el dudoso pergamino del Voto de Santiago que contenía el relato de la mencionada batalla, así como la concesión de esa renta en acto de gratitud al Apóstol por parte de Ramiro I. En realidad, la idea de nombrar a Teresa salió de los carmelitas descalzos y fue aceptada por las Cortes y por el rey sin apenas discusión: las Cortes porque lo consideraron de utilidad pública - los procuradores eran muy proclives a apoyar todo tipo de santidades-y porque identificaban la beatificación con «una especie de canonización regional limitada» ${ }^{11}$, y Felipe III, porque reforzaba la base de su soberanía, los intereses de la monarquía por encima de sus reinos, y su propia imagen como defensor de la $\mathrm{fe}^{12}$.

Sin embargo, se consiguió lo contrario, surgiendo una rápida oposición basada en la duda de si el rey en Cortes podía elegir patrón, si los procuradores podían intervenir en asuntos eclesiásticos y si se podía obligar al clero a venerar a una patrona nueva, que solo era beata, «inferior a los santos de España», y que no cumplía los mínimos marcados en el breviario romano. No solo lo argumentaron las instituciones vinculadas a la tradición jacobea - las primeras interesadas tanto en lo simbólico como, sobre todo, en lo materialsino que muchos prelados condicionaron su respuesta a la aprobación papal. Ante esto, las Cortes se retractaron y Felipe III suspendió las gestiones ante Roma. Muerto este rey, en 1622 Teresa fue canonizada por lo que, quizá, el compatronato fue un modo de impulsar su canonización ${ }^{13}$, conseguida con la de otros muchos santos, «naturales» de España, más cercanos a la realidad y, por lo tanto, bien diferentes al Santiago Matamoros. No en vano, la expulsión de los moriscos y la política pacifista de Felipe III habían dejado al Apóstol sin función bélica ${ }^{14}$. Conviene recordar, además, que por esos años se iniciaba la defensa de la inmaculada concepción de la Virgen y que estaba en auge el culto mariano en el Pilar de Zaragoza ${ }^{15}$, lo que iba también en detrimento de Santiago.

De nuevo, sin previo aviso, en 1626 Felipe IV remitió a las Cortes de Castilla su voluntad de proclamar a Teresa compatrona, lo que el papa concedió el

${ }^{10}$ HERBERS, 1999. NIETO ALCALDE y GARCÍA MORALES, 2004: 34. RUCQUOIE, 2007: 48-58.

11 THOMPSON, 2008: 296.

12 FEROS, 2004: 61. STRADLING, 1989.

13 REY CASTELAO, 2007-2008: 227; 2015a: 531.

14 REY CASTELAO 2015b: 235.

15 SERRANO MARTÍN, 2015.

Hispania, 2020, vol. LXXX, n. ${ }^{\circ}$ 266, septiembre-diciembre, págs. 783-816, ISSN: 0018-2141, e-ISSN: 1988-8368 https://doi.org/10.3989/hispania.2020.021 
21 de julio de 1627. En esta ocasión había dos novedades: fue el rey —o su valido, Olivares - quien tomó la decisión, y la bula hizo a la santa patrona de España «in universa hispaniarum regna», no solo de Castilla como en 1618, ya fuera por error o a petición de la legación de Felipe IV en Roma. Además, la propuesta del rey al Consejo de Castilla para llevar el asunto a las Cortes se hizo desde Zaragoza, lo que John Elliott vinculó con la política de la Unión de Armas $^{16}$. Para celebrar a Teresa, Felipe IV mandó hacer fiestas y sermones, en los que se indicaba que era una iniciativa suya y no «de otra persona» - Olivares-y los predicadores tuvieron que construir un discurso sobre la santa - esto es, su relato hagiográfico-, subrayar la faceta piadosa, que no política, de su elección y defender un patronato femenino. Para ello alabaron su ejemplaridad y su representatividad, sus virtudes y obras, su condición de maestra y profetisa, valedora de España, defensora de la fe y de la santidad, refugio y amparo de necesitados, favorecida por Dios, abogada contra los males, celosa del culto divino, escritora y doctora de la Iglesia, y, sobre todo, natural de España, a lo que podemos añadir que su sepulcro era auténtico y visitable ${ }^{17}$. Sin embargo, aun estando apoyada por el rey, Olivares y las Cortes, esa argumentación resultó débil ante las acciones del frente jacobeo, dirigido por el cabildo y por el arzobispo de Santiago, cuya existencia misma dependía del culto jacobeo. Tras ellos, ese frente fue seguido por muchas iglesias, instituciones y ciudades cuya antigüedad y prestigio dependían de la precoz predicación del Apóstol, lo que incluía a las de Portugal, como veremos.

La polémica subsiguiente tuvo como protagonista a Quevedo, autor en 1628 de Memorial por el patronato de Santiago y Su espada por Santiago, y de un poema contra el patronato de Teresa, escritos por su «devoción» al Apóstol - recompensada por el cabildo compostelano- - su respeto a la tradición y su condición de caballero de la Orden de Santiago. También lo hizo para atacar a Olivares y expresar su opinión de que el patronato era de derecho divino y, por lo tanto, competencia del papa; que las Cortes habían avalado una decisión general cuando no representaban a todos y que la alteración ponía en riesgo la protección apostólica y la «conservación» de España. Quevedo intentó además «trazar una suerte de unión de todos los países peninsulares basada en una contabilidad a lo divino», esto es, recordando las miles de batallas que los cristianos de Castilla, Aragón, Valencia y Portugal habían vencido gracias a su oportuna aparición ${ }^{18}$. Lo cierto es que las acciones del rey y de Olivares ante el papado no evitaron la reposición del Apóstol en su trono en 1629. Poco después, en 23 de marzo de 1630, se publicó el decreto papal sobre la elección de patronos para evitar conflictos como este, y la Congregación romana del

\footnotetext{
${ }^{16}$ ELLIOTT, 1986: 327-328.

${ }^{17}$ LÓPEZ ESTRADA, 1984: 654.

18 RODRÍGUEZ PUÉRTOLAS, 1994: 64.
} 
breviario restituyó el carácter universal e histórico de la tradición de Santiago, suprimido por la reforma de la liturgia ordenada por el Concilio de Trento.

Las lecturas políticas de estos hechos son numerosas y variadas, y se han centrado, en realidad, en aquello en lo que Quevedo puso su atención: la capacidad de las Cortes y de la monarquía para elegir y nombrar patronos; la oportunidad de elegir a una santa de características tan diferentes al patrono tradicional, lo que ha llevado a discutibles interpretaciones en clave de género, y si era un rasgo de modernidad y de una monarquía en fase reformadora y de cambio. $\mathrm{O}$ bien, si con ello se pretendía reforzar la unidad territorial por cuanto el segundo patronato se pretendía sobre España, aunque el acuerdo era solo de Castilla, todo lo cual daría más relevancia a la decisión de Felipe III, menos valorada, en general, que a la de Felipe IV, a su vez sobrevalorada al sumarse la acción de Olivares. Se olvida que ambos episodios fueron breves e igual de importantes - y no tanto como se dice-, que tenían antecedentes en la Edad Media — la Virgen y San Isidoro habían sido también patronos o protectores de los reinos cristianos-, y que si bien Santiago salió vencedor, todavía Felipe IV intentó sustituirlo por San Miguel, arcángel guerrero, en plena crisis política de los años cuarenta, lo que desmiente casi todas las teorías centradas en la figura beatífica y escritora de Teresa. Pero sobre todo se olvidan otros dos aspectos conectados.

Por un lado, ambos episodios se produjeron en plena crisis del culto jacobeo y de las peregrinaciones. La revisión de la liturgia romana había reducido a tradición piadosa la presencia del Apóstol en la península, al haber aceptado el cardenal Cesar Baronio los argumentos críticos aportados por el toledano García de Loaísa en un texto sobre la primacía de Toledo. Las protestas de Felipe II y Felipe III ante el papado consiguieron solo una restitución parcial ${ }^{19}$. Un nacionalismo historiográfico piadoso salió en defensa de la tradición — se defendían así las cualidades sagradas y universales de España-, seguido de una oleada de historias locales y de falsificaciones como los libros plúmbeos de Granada y los cronicones del jesuita Román de la Higuera, que intentaban reforzar las bases del culto a Santiago ${ }^{20}$. Esto choca con dos cosas: el cabildo compostelano había hecho «desaparecer» las reliquias del Apóstol en 1589 para evitar inspecciones poco favorables y, en 1592, una sentencia de la Chancillería de Valladolid había eximido a cinco obispados de Castilla de pagar el Voto de Santiago aceptando los argumentos del abogado González de Acevedo sobre la falsedad del pergamino de Ramiro I; aunque la sentencia de revista de 1616 la rectificaba parcialmente, la de 1628 la hizo definitiva, lo que supuso un duro golpe para la tradición jacobea.

Por otro lado, se ha de tener en consideración la dimensión territorial. Con frecuencia se ha vinculado a Teresa con la «nación española», no menos que a

\footnotetext{
19 REY CASTELAO, 1985; 2007-2008: 227-246.

20 KAGAN, 2010: 358. VAN LIERE, 2012: 121.
}

Hispania, 2020, vol. LXXX, n. ${ }^{\circ}$ 266, septiembre-diciembre, págs. 783-816, ISSN: 0018-2141, e-ISSN: 1988-8368 https://doi.org/10.3989/hispania.2020.021 
Santiago. Sin embargo, es necesario tener en cuenta que la Corona de Aragón tenía por patrón a San Jorge y que los territorios aragoneses no entraron en las polémicas del patronato, salvo en lo referente al Pilar de Zaragoza. En cuanto a los territorios italianos y americanos recibieron las órdenes con la novedad pero no se atendieron, quizá por la brevedad de ambos episodios. Tampoco consta que se enviaran a Portugal, que mantenía su autonomía y tenía un teórico patrón, también San Jorge, aunque este reino sí generó una intensa literatura al respecto, por razones de gran interés. En cuanto al Apóstol, en la real cédula de 9 de junio de 1643 instituyendo la ofrenda anual, Felipe IV afirma hacerlo por ser «notorios los beneficios y favores tan continuados que los Señores Reyes mis progenitores e yo y estos mis Reynos hemos recibido» de Santiago, «Patrón de ellos». En razón de esto, el rey disponía que: «estos mis Reynos de Castilla, también por reconocimiento, envíen al Santo Apóstol en cada un año perpetuamente, mil escudos de oro», cantidad que se libraría «en la renta de millones del dicho mi Reyno de Galicia» ${ }^{21}$. Está claro que Felipe IV vinculaba a su dinastía y a Castilla con la tradición apostólica, si bien se pagaba con tributos sobre los gallegos. A mayor abundamiento, y también para hacerse perdonar los cambios de patronato, las Cortes de Castilla ofrecieron en 1646 una segunda cantidad de 8272 reales a entregar a la catedral compostelana en la fiesta de la Traslación del 31 de diciembre.

\section{El test territorial: el Apóstol en Portugal}

El caso portugués es muy interesante por cuanto los cambios del patronato en Castilla coincidieron con el desarrollo del orgullo nacional, de la conciencia del pasado y de la identidad de Portugal — nunca desaparecidos — ${ }^{22}$, como reacción a la política unionista de Olivares, para cuya respuesta se empleó una tradición histórica — en parte inventada - de intención política ${ }^{23}$. Pero se daba la paradoja de que ese pasado estaba vinculado a Castilla a través de la predicación del Apóstol, origen de las iglesias portuguesas y del propio reino; del patronato, no en vano Santiago fue patrón de Portugal hasta 1385, y de la renta del Voto de Santiago, que era percibida por los obispos de Braga, Coimbra y Porto fundamentándose en el relato castellano-leonés ${ }^{24}$. Así pues, los cronistas portugueses tuvieron que reinterpretar ese entramado para diferenciar a su reino de Castilla. Para esto, reivindicaron que la predicación se había iniciado

${ }^{21}$ La reproduce, entre otros, Pablo PÉREZ COSTANTI, 2008: 452.

22 SERRAO, 1979: 422.

${ }^{23}$ CARDIM, 1998. ÁLVAREZ JUNCO y DE LA FUENTE 2017: 124.

${ }^{24}$ MATTOSSO, 1988. MARQUES, 1992: 50. CAPELA 1979. OLIVEIRA MARTÍNS, 1998.

Hispania, 2020, vol. LXXX, n. ${ }^{\circ}$ 266, septiembre-diciembre, págs. 783-816, ISSN: 0018-2141, e-ISSN: 1988-8368 https://doi.org/10.3989/hispania.2020.021 
en Portugal, «inventaron» a Pedro de Rates, primer discípulo ibérico de Santiago, y lo hicieron primer obispo de Braga para afianzar la sede bracarense como primada, ya no solo de Portugal, sino de la unión de las coronas, en detrimento de Toledo. Es decir, en el período de las polémicas castellanas del patronato, Portugal asumió la defensa de Santiago, tanto el evangelizador como el caballero, porque era parte de su propia tradición y la base de su antigüedad y de la primacía de su iglesia. Además, también reelaboró el relato para reforzar su identidad - en el Norte se intentó crear un patrono propio, portugués y pacífico-, mientras Castilla se jugaba la suya cambiando el patronato.

Hasta entonces puede decirse que el papel identitario de los santos protectores no había tenido en Portugal la misma fuerza que en Castilla o, al menos, no hubo continuidad ni una identificación con los patronos sino de estos con las dinastías reinantes. De hecho, Santiago rigió en el Portugal independiente hasta que Afonso IV le buscó una alternativa, de modo que en la batalla de Aljubarrota (1385), según Faria i Sousa «se oyó llamar de una parte por Santiago i de la otra por san Jorge», venciendo los portugueses a los castellanos; la adopción de San Jorge, cuya imagen era la de un caballero con lanza luchando contra un dragón y cruz roja sobre fondo blanco en el escudo - muy parecida a la de Santiago - , fue ratificada por Joao I como una forma de agradecer la colaboración de Inglaterra, que lo tenía por patrón, en la «difesa da independencia e a resistencia à absorçao polo poderoso reino vizinho $»^{25}$. El hecho de que San Jorge fuera también patrono de Aragón, según opiniones recientes ${ }^{26}$, vincularía el particularismo portugués con el catalano-aragonés por oposición a Castilla - no a España-, pero creemos que solo lo sería en las formas. La tradición atribuyó las victorias posteriores a San Jorge, aunque fue más un santo de la capital, Lisboa, de la recuperación de la independencia y de los Avis que del reino, ya que en el Portugal septentrional había otras devociones.

En el siglo XV, el patronato de San Jorge estaba en decadencia - aunque la crónica de Fernando Lopes (1419) reitera la devoción popular y el grito de los soldados «Portugal e Sâo Jorge». El rey Manuel I nombró patrono al Anjo da Garda, que no llegó a arraigar. En ese siglo surgió otra línea que atribuía a Cristo la ayuda directa, sin intermediarios: de hecho, la crónica de 1419 otorga un valor mesiánico al 25 de julio de 1139, fiesta de Santiago, día de la victoria del conde Alfonso Enríquez en Ourique sobre los musulmanes gracias a la aparición de Cristo Señor de los Ejércitos, cuyas llagas quedarían impresas en el escudo de Portugal, en tanto que era el propio Dios quien habría hecho rey a Alfonso $^{27}$. Este mito fundacional de Portugal se consolidó a fines del XVI en la Historia de Portugal de Fernando de Oliveira, partidario del prior de Crato en

\footnotetext{
${ }^{25}$ FARIA I SOUSA, 1628: 451.

26 ÁLVAREZ JUNCO y DE LA FUENTE, 2017: 124.

27 RODRÍGUEZ PUÉRTOLAS, 1994: 64. LOPES ALVES, 2008.
} 
la guerra con Felipe II, y en Antigüidades da história de Andrea de Resende (1593), y fue avalado por un códice falsificado en Alcobaça ${ }^{28}$. En paralelo, se mantenía y fomentaba un mito cívico-religioso, el mesianismo sebastianista, basado en rumores de que el infante don Sebastián vivía y volvería a reinar ${ }^{29}$.

A fines del siglo XVI, Portugal fomentaba el culto a varios santos naturales como forma inconsciente de exaltar a «la patria» y, a comienzos del siglo XVII, vivió una oleada de santos paralela a la de Castilla, en especial los relacionados con Lisboa. En 1612 se «descubrió» en esa ciudad el cuerpo incorrupto de la reina Isabel, canonizada en 1625 - Felipe IV quiso hacerla patrona de Portugal - y en 1614 el sepulcro de San Vicente, patrón de la ciudad. Mientras, en las crónicas se proclamaban las devociones plurales de los reyes, que incluían Monserrat, Guadalupe y Santiago, según Nuñes de Leao ${ }^{30}$; Faria i Sousa refleja que don Sebastián y don Manuel eran devotos del Sacramento; Juan I, de Santa María de Oliveira y don Duarte, de la Santa Cruz y de la Inmaculada ${ }^{31}$. Sousa Macedo subraya la abundancia y autosuficiencia de los santos propios de Portugal y la tradición de que Alonso Enríquez, Alonso IV y Juan I se encomendaban a la Virgen de Oliveira en las luchas contra los castellanos ${ }^{32}$. En resumen, los cronistas no mencionan a los antiguos patronos de los Avis, sino que subrayan la devoción mariana e inmaculista de sus reyes ${ }^{33}$.

Al no haber un referente claro, se procedió a buscar un patrono de entre los miles de mártires y santos que en Portugal habían nacido del celo religioso de los portugueses «gente melancólica y por eso severa, aficionada a fiestas religiosas, votos y peregrinaciones», según afirmaba el humanista Núñez de Leao $(1610)^{34}$. Fray Bernardo Brito y fray Antonio Brandâo, cistercienses de la abadía de Alcobaça y cronistas del reino elegidos por los Felipes, en los primeros volúmenes de Monarchia Lusitana $(1597,1607)^{35}$, verdadera historia nacional de Portugal, y el memorial de Nuñez de Leâo defendían que Santiago había predicado primero en Portugal, dejando a su discípulo Pedro, martirizado en Rates, como encargado de crear la iglesia de Braga, capital provincial de los romanos en la que había una comunidad judía, explicando así la presencia del Apóstol y la primacía bracarense frente a Toledo.

28 BUESCU, 1993: 9. BORGES, 2012.

29 ACOSTA LOBO, 2012.

30 NUÑES DE LEÂO, 1610.

31 FARIA I SOUSA, 1628: 499.

32 Sousa afirmaba que «tantos santos en tan pequeño circuito de tierra... es particular influencia del cielo»; «y así no solamente son bastantes los santos de Portugal para ennoblecer un Reyno..., sino que honran todos los del mundo», SOUSA MACEDO, 1631: 87, 91.

33 SERRAO, 1979: 395; 1980: 337. DA COSTA, 1964. DOS SANTOS, 1996. MAGALHAES GODINHO, 2004.

${ }^{34}$ NUNES DE LEÂO, 1610: 128.

${ }^{35}$ BRITO, 1597; 1607.

Hispania, 2020, vol. LXXX, n. ${ }^{\circ}$ 266, septiembre-diciembre, págs. 783-816, ISSN: 0018-2141, e-ISSN: 1988-8368 https://doi.org/10.3989/hispania.2020.021 
Los cronistas portugueses se posicionaban de ese modo ante el contenido de la Historia de España $(1592,1601)$ del padre Juan de Mariana, obra de fuerte sentido mesiánico que pretendía reforzar la unidad territorial, Portugal incluido ${ }^{36}$, y ante su tratado De adventu Iacobis Apostolis Maioris (1609). En ambos, este historiador jesuita trataba de depurar la tradición jacobea y revisar los fundamentos de esta, en especial los textos de San Isidoro de Sevilla, y acogía la tesis de la comunidad judía. Mariana - favorable a Toledo - fue atacado por varios autores castellanos por cuanto, en una sociedad obsesionada con la limpieza de sangre, no podía admitirse la presencia hebrea. No era una opinión nueva ni heterodoxa — estaba en Flavio Josefo-, ni era excepcional — la sostenía entonces el agustino fray Jerónimo Román, cronista al servicio tanto de Braga como de Compostela ${ }^{37}$ - pero el éxito de Mariana le dio gran repercusión. Por esta razón, se prohibió al jesuita intervenir en materia de gobierno - así se conceptuó- y su tratado acabó expurgado por la Inquisición en $1612^{38}$. A los cronistas portugueses les convenía el argumento judío porque daba verosimilitud a la precoz visita evangelizadora de Santiago, pero no así la depuración de los textos medievales, ni que el Apóstol hubiera entrado por Galicia, por lo que fueron contestados desde el entorno del gallego don Diego Sarmiento de Acuña, conde de Gondomar, de donde salieron dos vidas del Apóstol, las de Castellá Ferrer (1610) y la de fray Fernando de Ojea (1615), destinadas a redondear la versión clásica, y empleadas a su vez por los cronistas portugueses posteriores para reforzar sus argumentos.

Reelaborada la tradición, Pedro de Rates ocupaba el centro de atención de esos cronistas, aunque la verdadera promoción se hizo desde la iglesia de Braga, cuyos prelados fundamentaban la primacía de esa sede en la condición de Pedro como primer obispo. La leyenda de Pedro, basada en una más que sospechosa biografía escrita por Caledonio (Vita S. Petri Ratensis), varía entre los autores. En esencia, se trataría de un natural de Portugal - las versiones más tardías lo hacen judío - , primer discípulo de Santiago y mártir decapitado por convertir al cristianismo a los pueblos del norte de Portugal o, en otra versión, por haber salvado de una enfermedad mortal y convertido a una joven princesa pagana. En todo caso, Santiago lo habría elegido como primera piedra de su Iglesia, de ahí el nombre de Pedro. Siglos después, un ermitaño, Félix, localizaría su tumba, señalada por unas luces en la sierra de Rates, y allí se hizo una iglesia para alojarla, aunque en 1552 los restos fueron llevados a Braga. El relato hagiográfico responde con precisión a lo que hemos indicado al principio y guarda muchas similitudes con el del Apóstol Santiago.

A primera vista, la operación se hizo para defender la primacía de Braga, cabeza de la iglesia portuguesa desde el nacimiento del Portugal independiente,

\footnotetext{
36 KAGAN, 2010: 172. REY CASTELAO, 1985. FRANCO, 2000.

37 BOUZA, 1998: 52.

38 GARCÍA HERNÁN, 2004: 127; 2006: 125-150.
} 
posición discutida por Lisboa. Esto generó un grave conflicto en el Concilio de Trento protagonizado por el arzobispo bracarense fray Bartolomé de los Mártires, quien también reclamaba para sí la primacía hispana ostentada por Toledo. Frei Luis Cacegas, en su biografía de fray Bartolomé (1619), relata su retorno de Trento a través de Francia, pasando por Toulouse, donde visitó el «otro» sepulcro de Santiago ${ }^{39}$, y por Zaragoza para visitar el Pilar, todo lo cual iba en contra de Compostela. Pero el origen apostólico era también necesario para Braga por cuanto los arzobispos cobraban el Voto de Santiago «com a mesma razâo e fundamento que forâo prometidos ao Santo», por lo que defendían la historicidad de la batalla de Clavijo y la elección del Apóstol como patrono por Ramiro I, aunque matizando que «destedia en adiante ficuo em Espanha o costume de rôper as batalhas com o nome de Santiago» ${ }^{40}$. Es decir, se asumía la tradición jacobea, por vía de Pedro de Rates en la cuestión de la primacía y del propio Santiago para cobrar el Voto, pero, en plena crisis castellana del patronato, se sugerían elementos contrarios a Compostela, no en vano Braga también disputaba antigüedad y primacía con esa sede gallega.

Durante el segundo episodio del patronato, las circunstancias de Portugal habían cambiado y la Iglesia, de enorme influencia social, había adquirido un peso simbólico clave contra la política de Olivares. En ese contexto, Manuel de Faria i Sousa publicó Epitome de historias portuguesas (1628), donde se defiende a Portugal como origen del cristianismo - según San Isidoro, Santiago había estado donde se ponía el sol, en Galicia, que era parte de «Entre Duero y Miño»- Allí había dejado a uno de sus discípulos, Pedro, para hacer su iglesia en Braga, y a otro, Torcuato, en Citania: martirizados ambos, serían el germen de la fe en Portugal. Otros discípulos irían a Granada — «después que volvieron de Judea con su maestro»- y en Roma «fueron por san Pedro constituidos en dignidad pontifical», en los mismos años en los que Herodes, miembro «de la Casa Real Judaica» había visitado Hispania porque «vivían en ella muchos judíos, i tenían sus sinagogas en las ciudades principales ${ }^{41}$. Por otra parte, Faria i Sousa trataba de fundamentar mejor el Voto de Santiago, retrasando la batalla de Clavijo a 934 y al reinado de Ramiro II, y reiterando la protección del Apóstol en las batallas contra «los moros» —en especial, la toma de Coimbra-, hasta la independencia de Portugal.

Poco después, Antonio de Sousa de Macedo publicó Flores de España, excelencias de Portugal (1631). Según su relato, Santiago predicó primero en Portugal — que era parte de España-, la primera parte del mundo donde se

${ }^{39} \mathrm{La}$ autenticidad de este otro sepulcro era defendida por los cronistas franceses, aunque en Francia y en la misma época había otro cuerpo de Santiago que también tenía importantes defensores. PÉRICARD MÉA, 2011.

${ }^{40}$ CACEGAS, 1619: 58, 107, 158, 160.

${ }^{41}$ CACEGAS, 1619: 260, 286.

Hispania, 2020, vol. LXXX, n. ${ }^{\circ} 266$, septiembre-diciembre, págs. 783-816, ISSN: 0018-2141, e-ISSN: 1988-8368 https://doi.org/10.3989/hispania.2020.021 
predicó la fe y se recibió la ley divina. Sin embargo, recoge también la predicación de san Dionisio, discípulo de San Pablo, y subraya que fue el propio Dios y no un patrono, quien «en el campo de Ourique le dio título de rey» a Alfonso Enríquez. Sin duda, la clave de Sousa está en Pedro de Rates, cuya existencia daba a Braga prioridad sobre el Pilar de Zaragoza, templo de fama creciente. Como resultado, los primeros nueve discípulos de Santiago, portugueses todos, fueron los primeros santos, como luego fueron portugueses los defensores de la fe contra herejes y moros. Para reforzar a Braga frente a Toledo, Sousa atacaba a García de Loaisa por «dezir que Santiago nunca avia venido a España», y a la propia Toledo, nunca visitada por Santiago por «ser siempre poco estimada en España» y por haber sucumbido a los musulmanes, mientras Braga nunca renunció a la fe y siempre tuvo obispos ${ }^{42}$. Poco después, fray Antonio Brandâo, en la tercera parte de Monarchia Lusitana (1632), defendía la tradición de Santiago y que este siempre había ayudado a los «christâos de Espanha», pero también afirmaba la primacía de Braga, que tenía como sufragáneos a los obispados de Galicia, mientras que Compostela había llegado a su grandeza «pouco \& pouco» ${ }^{43}$.

Este ciclo remata cuando el arzobispo de Braga, Rodrigo Dacunha, publicó dos obras, un tratado jurídico en 1632 y un libro de historia en 1634, para defender la primacía de su iglesia; ambas están dedicadas a la Virgen, patrona de su iglesia - no lo era Pedro de Rates - , lo que está en línea con el creciente culto mariano que Lisboa promovía. Aunque Dacunha recoge que el apóstol Pablo predicó en España, ataca a García de Loaisa por desautorizar a Compostela, «chegando a negarlle ter en sy o corpo do glorioso apostolo», «lo que so velhas e gente ingorante criâo e publicavâo», atribuyendo "semelhantes patranhas» al propio Loaisa. Además, negaba que Santiago hubiera predicado en Toledo ${ }^{44}$ y afirmaba que lo había hecho en Braga, elegida por aquel por ser la más principal ciudad de Hispania. Allí Santiago habría realizado muchos milagros, a cuya vista «convertironse tamben alguns dos Iudeos de que avía grande número en Braga assi pella riqueza e comercio da cidade», destacando en especial la resurrección de Pedro, transformado por Dacunha en «santo profeta judeo de naçao que ali viera dar como utros cativos mandados de Babylonia por Nabucodonosor»». Santiago pasó por Zaragoza en su primer intento evangelizador y cuando volvió a Braga, al no haber iglesia, puso al lado del templo de Isis otro en honor a la Virgen - «edificado pello patrâo e defensor de Hespanha», matiza el autor - y se lo dio a Pedro declarándolo obispo de la principal iglesia de España, en cuya condición tenía el poder de nombrar obispos en Galicia y Portugal, lo que fue respondido con contundencia por Diego de

\footnotetext{
42 SOUSA DE MACEDO, 1631: 56.

${ }^{43}$ BRANDAO, 1632: 78.

${ }^{44}$ DA CUNHA I SILVA, 1634: 28, 37, 45, 93; 1632: 13.
}

Hispania, 2020, vol. LXXX, n. ${ }^{\circ}$ 266, septiembre-diciembre, págs. 783-816, ISSN: 0018-2141, e-ISSN: 1988-8368 https://doi.org/10.3989/hispania.2020.021 
Castejón en favor de Toledo ${ }^{45}$. Sorprende que, en el tono reivindicativo de su obra, Dacunha no utilizase el pío latrocinio cometido en 1102 en la sede de Braga por el obispo compostelano Diego Gelmírez, llevándose las reliquias de los discípulos del Apóstol ${ }^{46}$, sino que, al contrario, agradeciese al cielo que en 1590 se hubiera hallado en la catedral bracarense parte de aquel «precioso thesouro» ${ }^{47}$. El relato de don Rodrigo, basado en falsarios como Dextro, es el más acabado en la construcción de la imagen de Pedro de Rates.

Sin embargo, cuando se produjo la ruptura de Portugal con Felipe IV, ese pacífico mártir portugués no fue elegido patrono, quizá por ser el símbolo de la primacía de Braga frente a Lisboa, y tampoco fue recuperado San Jorge, por serlo de los Avis. La elección recayó en la Virgen, cuya exaltación era visible ya en los textos comentados o en Trunfos Lusitanos (1632) del padre Antonio Soares de Albergaria. Esta obra, en la que se presenta a «nossa senhora da Asunçao protectora do reyno de Portugal, patrona ec mater Piisima Lusitaniae», fue clave en el proceso que llevó a la secesión de 1640. No obstante, Joâo IV, a quien la propaganda, sobre todo la eclesiástica, presentaba como el príncipe oculto, Sebastián ${ }^{48}$, justificó su decisión ante las Cortes de Lisboa, en 1646, en la devoción mariana de los antiguos reyes, para manifestar ante aquellas su voluntad de designar a la Virgem de la Conceição como patrona y prometiéndole una ofrenda anual de cincuenta cruzados de oro. Por su parte, el Desembargo do Pazo invocó explícitamente esa devoción y la esperanza de obtener de la Virgen protección frente a los enemigos. En realidad, la patrona de la Casa de Braganza pasaba a serlo del reino y, para hacer efectivo el patronato, fue preciso hacer una campaña de propaganda, mediante fiestas y medallas, y hacer jurar a todas las corporaciones — desde los graduados en Coímbra, a las cámaras del reino, cabildos, y clero ${ }^{49}$ - para hacer efectivo el patronato.

Si se concede capacidad identitaria a un patronato, resulta sorprendente que Joâo IV tomase esa opción sabiendo que los Austrias habían asumido el dogma de la Inmaculada como una batalla por su propio prestigio, no en vano tenían a la Virgen por su protectora, en especial Felipe IV $^{50}$. De hecho, la Universidad de Salamanca había impuesto el mismo juramento en 1638. Rafael Valladares sostiene a este respecto que la castellanofobia portuguesa era antropológica y cultural más que política y, por lo tanto, no era incompatible con aceptar la moda inmaculista castellana ${ }^{51}$. Por su parte, Pedro Cardim considera que, después de 1640, el sentido de pertenencia, patria, ancestralidad y memoria histórica se

${ }^{45}$ CASTEJÓN Y FONSECA, 1645.

46 FANDIÑO FUENTES, 2017: 119-140.

47 DA CUNHA I SILVA, 1634: 176.

48 STROBEL, 2001. ACOSTA LOBO, 2012.

49 SERRAO, 1982: 158-159.

50 ALMEIDA y MATOS FERREIRA, 2012: 75-90. CHAVES, 1967: 57-87.

51 VALLADARES, 2000; 2004: 38, 239, 301-309. 
reforzó y contaminó de elementos trascendentes y providencialistas, y que la ambigüedad es típica de un proceso de secesión cuando «resulta difícil desarrollar un vocabulario capaz de subrayar la diferencia mediante el empleo de un lenguaje que durante tantos años sirvió para acentuar la identidad, la unanimidad, la comunidad». Además, Cardim subraya que el reconocimiento de la Virgen como patrona no se solicitó al papa, por cuanto este no reconocía a los rebeldes portugueses ni aceptaba que designaran obispos, sino que se usó como arma para influir en Roma y para proclamar la autonomía frente al papado ${ }^{52}$.

Conviene tener en cuenta que con Felipe IV en 1643 hubo un serio intento de hacer patrono de Castilla a San Miguel Arcángel, que lo había sido de los godos, aunque en ese mismo año el rey estableció la ofrenda anual al Apóstol. En 1646, las Cortes de Castilla imitaron ese gesto con otra ofrenda anual, reconociendo el patronato de Santiago ${ }^{53}$. Es decir, la diferencia con respecto a Portugal se marcó desde Madrid, retomando al santo de la guerra como estandarte - San Miguel también era un guerrero-, al tiempo que, frente a la sublevación catalana, se reforzó el culto a la Virgen en el Pilar de Zaragoza. El binomio tradicional se había impuesto.

\section{El TEST SOCIAL: EL APóstol EN MEDIOS POPUlARES}

La mayor parte de quienes han estudiado los santos patronos dan por hecho que contaban con el fervor popular, por sí mismos o por oposición a otros santos. En el caso que nos ocupa, Américo Castro aseguraba que «los españoles» y «las masas favorecían al Apóstol», y muchos años después, Erin Rowe manifestaba que la popularidad de Santiago estaba asentada en su ayuda a Castilla en la Reconquista ${ }^{54}$. En el lado opuesto, López Estrada defendió la existencia de un acuerdo entre el rey y los súbditos en elevar a Teresa al compatronato, y T. Kendric y Teófanes Egido, que la santa era «popular y admirada», aunque este último dice lo mismo de la proclamación inmaculista bajo Felipe III y Felipe IV, en lo que coincide Rafael Valladares al hablar de Portugal ${ }^{55}$. Sin embargo, siendo esenciales el grado de popularidad y la recepción de los cambios para calibrar la relación entre patronato e identidad, y la identificación de

52 CARDIM, 2004: 355; 2008: 207.

${ }^{53}$ Las dos ofrendas, en especial la primera, pueden interpretarse también en términos políticos, no en vano se instituyeron en plena crisis con Portugal y Cataluña, cuando la Corona necesitaba la colaboración de los reinos: eran los dos únicos actos en los que la monarquía se hacía ver y oír mediante un representante - un oidor de la Audiencia de Galicia y, en algunas ocasiones, el gobernador de ese reino- en una ciudad del señorío del arzobispo de Santiago. Véase otra interpretación en LÓPEZ LÓPEZ, 2008: 41.

${ }^{54}$ CASTRO, 1929; 1948. ROWE, 2011.

55 LÓPEZ ESTRADA, 1984: 654, 660, 661, 670. KENDRIC, 1960. EGIDO, 2003: 100-105. 
esta con sectores ajenos a los gobernantes y a las elites, las pruebas son escasas y las que hay son desde el punto de vista del emisor o de sus intermediarios y no de los receptores ni de las gentes del común, habida cuenta de que estas eran analfabetas en su inmensa mayoría, y que estuvieron al margen de las batallas literarias, jurídicas y canónicas que marcaron estos episodios.

Dada la intervención de las Cortes en la elección de patronos, Teófanes Egido puso la atención en los procuradores, partiendo de que su universo mental representaría a los castellanos. Esto puede ser cierto en lo referente al culto mariano, al apoyo de los procuradores a beatificaciones y canonizaciones de santos naturales y a su compromiso mesiánico en tiempos de crisis. Pero no lo es en su representatividad, limitada a un sector concreto de las ciudades de la Corona de Castilla, de modo que no puede deducirse de la actuación de los procuradores que Teresa fuera «signo evidente de la identidad castellana», sino solo de las oligarquías de las ciudades con voto en las Cortes y de las ciudades con voto en estas ${ }^{56}$. Por otro lado, en la oleada de santidad que llegó a 1630, las Cortes avalaron muchas iniciativas ajenas, ya fueran de santos propuestos por órdenes religiosas en función de sus propios intereses, ya por la Corona como afirmación de la monarquía, en especial antepasados de los reyes como Sancha, hija de Alonso IX, Alfonso VIII, Fernando III o Isabel de Portugal. En este sentido, las iniciativas referidas al patronato también eran ajenas.

Las pruebas de que esas iniciativas llegaran más allá de quienes las promovieron son indirectas e imprecisas, por lo que es incierto el efecto difusor y de captación ejercido mediante sermones, poemas, piezas teatrales, votos, procesiones, imágenes o, incluso, juramentos, como sucedió en Portugal para imponer João IV el de la Concepción. Por eso mismo es difícil observar qué pasó realmente con Teresa, dado que no hubo tiempo para construir una imagen ${ }^{57}$, ni para expandir su culto, por lo que nos centraremos en el Apóstol para ver si era o no un patrón aceptado y popular, habida cuenta de que tanto en Castilla como en Portugal se asociaba su nombre con el pago anual del Voto de Santiago y con la intensa conflictividad social que este generaba.

Desde la Edad Media hasta el período que nos ocupa, la imagen de Santiago - y en concreto, el Matamoros - tenía una aparente utilidad para la monarquía, difundida en historias del santo - en especial, la de Castellá Ferrer-, en textos litúrgicos, piadosos o jurídicos, y en el arte de la Contrarreforma, tanto en ciudades como en templos rurales, en especial en los años de la discusión del patronato ${ }^{58}$. Como demostró Lidwine Linares, la iconografía del Apóstol era variada y tenía una estrecha relación con la tradición recogida en crónicas de ciudades y regiones:

${ }^{56}$ EGIDO, 2003: 100-105.

57 GATTER, s. a. ROWE, 2006 b.

58 CABRILLANA CIÉZAR, 1999. CIVIL, 1993: 75. CRUZ VALDOVINOS, 1999: 123139. GÓMEZ LÓPEZ, 2004: 87. PÉRICARD MÉA, 2011.

Hispania, 2020, vol. LXXX, n. ${ }^{\circ} 266$, septiembre-diciembre, págs. 783-816, ISSN: 0018-2141, e-ISSN: 1988-8368 https://doi.org/10.3989/hispania.2020.021 
en todas partes, el Santiago caballero; peregrino en zonas del Camino; orante ante la Virgen en Zaragoza y Aragón; en la batalla de Clavijo, en La Rioja; y en Galicia serenamente muerto en la traslatio desde Palestina ${ }^{59}$. Ahora bien, podría tener un efecto negativo, ya que la iconografía jacobea estaba vinculada con el ámbito de la Orden de Santiago, como lo era en Portugal ${ }^{60}$, y con los linajes de sus caballeros, por lo que la imagen del santo era la del poder señorial y nobiliario; lo mismo sucedía en las diócesis sufragáneas del arzobispo de Santiago, que ocupaban de Galicia a Badajoz, varias de las cuales se abstuvieron en el debate o se decantaron por Teresa en la polémica del patronato. Finalmente, el Santiago Matamoros figuraba en los miles de paulinas y poderes que cada año presentaban los cobradores del Voto para exigir su pago y adornaban las sentencias que lo imponían por vía judicial tras largos y costosos pleitos, al igual que sucedía en Portugal ${ }^{61}$.

En la dimensión escrita, era general la referencia a Santiago en las crónicas urbanas, invocado como evangelizador, ya que su presencia precoz valía a las ciudades para reclamar antigüedad, primacía (Toledo, Mérida) y santidad, de ahí que en su cronicón de Dextro, el falsario jesuita Román de la Higuera aportase la lista de núcleos visitados por el Apóstol. Lo mismo hicieron luego los carmelitas con las ciudades que se pronunciaron a favor de Teresa, para demostrar su aceptación general en Castilla ${ }^{62}$. Sin embargo, las crónicas urbanas vuelven a limitar el patronato y sus cambios a Castilla — en Aragón dominaba San Jorge - , y, de nuevo, no se sabe quién las leía y quién recibía un mensaje elaborado por y para las oligarquías urbanas que las promocionaban en función de sus propios intereses, no los del Apóstol ni los de su patronato ${ }^{63}$.

Un indicador más cercano a los sectores populares es, sin duda, la titularidad de las numerosas ermitas y cofradías que después de Trento se crearon por todas partes. Es ahí donde la ausencia de Santiago - y luego de Teresa - se hace evidente, frente al dominio de las dedicadas a la divinidad y a la Virgen, y a los santos - San Sebastián, San Roque, San Antón - que tenían una especialización - epidemias, plagas, desastres - útil para el común, de lo que carecían los patronos generales ${ }^{64}$. Esto se comprueba tanto en Andalucía, donde las cofradías de Santiago eran una rareza en el período considerado ${ }^{65}$, como en La Mancha, donde a fines del siglo XVI o a mediados del XVIII el Apóstol no alcanzaba el $3 \%$ de los titulares de ermitas y cofradías $^{66}$; baste decir que la

${ }^{59}$ LINARES, 2008: 13.

${ }^{60}$ FERREIRA FERNANDES, 2016: 296-310. CALVO DOMÍNGUEZ, 1999.

${ }^{61}$ REY CASTELAO, 1985; 1993. CAPELA, 1979. OLVIEIRA MARTINS, 1998.

${ }^{62}$ ROWE, 2011.

${ }^{63}$ REY CASTELAO, 2008.

${ }^{64}$ Responde al modelo de la religiosidad local. CHRISTIAN, 1991: 206-213.

${ }^{65}$ PÉREZ GONZÁLEZ, 2017.

${ }^{66}$ CAMPOS Y FERNÁNDEZ DE SEVILLA, 1986. MARTÍNEZ GIL, 2000: 665-666. NALE, 2008: 162, 164, 177. 
Virgen superaba un tercio del total. Lo mismo sucedía en Galicia: allí, la toponimia jugaba a favor de Santiago —el 7,9\% de las parroquias llevaban su santo-, ya que solo era superado por María $(20,1 \%)$ y Pedro $(8,2 \%)$, pero apenas había santuarios dedicados a aquel. Incluso en la diócesis compostelana, donde titulaba al $11 \%$ de las parroquias, las cofradías jacobeas no llegaban al $1 \%$ entre 1594 y 1630, y cuando aparece alguna, resulta ser el santo titular de la parroquia $^{67}$. En América, donde muchos pueblos fueron llamados Santiago y muchos pobladores llevaban el nombre Diego, no hubo un movimiento cofradial con su advocación ${ }^{68}$.

La frecuencia de María y de Santiago como titulares de parroquias es una herencia medieval y no refleja los comportamientos populares de nuestro período, pero sí podría haber tenido efecto en los santos invocados en los testamentos o impuestos como nombres de los niños, gestos que vinculan la influencia del clero con las decisiones privadas ${ }^{69}$. En lo primero, la abundante bibliografía al respecto concuerda en sus datos con los expuestos: por ejemplo, en Huelva las misas de encargo se dedicaban a la Virgen $(34,8 \%)$ y a Cristo $(9,7 \%)$ y un $52,9 \%$, a los santos, pero estos eran José, Juan, Pablo, Pedro o Antonio, no Santiago, y lo mismo sucedía en toda Castilla ${ }^{70}$.

En lo segundo, considerando el nombre como indicio de la afinidad con el santoral, hemos recurrido a trabajos sobre onomástica y realizado una aproximación mediante los nombres masculinos de demandantes y demandados de pleitos civiles de los territorios de la Chancillería de Valladolid y de la Audiencia de Galicia, y en escrituras notariales del ámbito compostelano. Se trata siempre de adultos de toda condición social, aunque en su mayoría rurales, de los que hemos retenido solo los de más del $5 \%{ }^{71}$. Con esto pretendemos medir la frecuencia del nombre de Santiago comparando la década final del siglo XVI con los años centrales del XVII y diferenciar los territorios según pagasen o no el Voto de Santiago. Dado que el pago de esta renta era motivo de rechazo general y que el período tratado aquí coincide con el de máxima conflictividad, el uso o no de ese nombre puede ser significativo. Ahora bien, Santiago es la denominación presente en topónimos urbanos y rurales y en instituciones - Orden de Santiago, conventos, hospitales- pero

${ }^{67}$ SAAVEDRA 1995: 328-354. GONZÁLEZ LOPO, 1996: 157-192; 1994: 53.

${ }^{68}$ MÉNDEZ MARTÍNEZ, 1993: 93. ÁLVAREZ GILA, ANGULO MORALES y RAMOS MARTÍNEZ, 2014.

${ }^{69}$ BILLY, 2018.

70 LARA RÓDENAS, 1999: 407-466. GARCÍA FERNÁNDEZ, 1990.

${ }^{71}$ Los casos consultados figuran en las tablas 1 a 4: 1828 pleitos civiles de la Chancillería de Valladolid, 384 de la Real Audiencia de Galicia, desde 1580 a 1640, y 238 escrituras notariales de la ciudad de Santiago. Los datos se han extraído mediante consulta en el portal Pares, depurando los resultados para evitar duplicaciones de personas y practicando un muestreo aleatorio para que entrasen todos los grupos sociales y las procedencias rurales y urbanas. 
apenas aparece en personas. En general se usaba Diego en Castilla; Jaime, en la Corona de Aragón; Jácome, en la diócesis de Santiago y, en general, en toda Galicia; y Jacobo, en el País Vasco, por lo que cabe preguntar si las gentes del común asociaban estas variantes con el Apóstol, dado que nada indica que así fuera.

En todas partes, Juan era el nombre de uso más general, ya fuera el apóstol o el Bautista, seguido de Francisco y Antonio, lo que, en estos dos casos, obedece a la creciente acción de los franciscanos. Lo mismo sucedía en Francia, pero allí Santiago llegaba a una quinta parte, equiparado a Pedro y otros apóstoles $^{72}$, mientras que en Castilla y Portugal no superaba el 10\%. Donde no se pagaba el Voto, eso no dio más popularidad a Santiago, irrelevante en la onomástica, ya fuera en Navarra - dominaban Juan 23\% y Martín 21,7\% - o en la corona de Aragón —en Castellón eran Juan, Miguel, Francisco, Domingo - ${ }^{73}$. Tampoco arraigó entre los extranjeros asentados en España, que solían querer adaptarse a los gustos locales: los irlandeses, por ejemplo, lo incorporaron después de 1621, dentro de la tendencia a asumir nombres continentales ${ }^{74}$. Entre los pobladores hispanos en México, en 1540-1660, Diego era el segundo en frecuencia (del 7\% al 8,5\%), pero decayó de forma constante desde 1620 $(6,7 \%), 5 \%$ en $1640,4 \%$ después $^{75}$, cifras similares a las de los pobladores de Madeira en el siglo XVI — portugueses en su mayoría-, de los que el 5,75\% se llamaban Diogo ${ }^{76}$.

En cuanto a los territorios de Castilla, podría suponerse a Asturias y a Galicia una mayor afinidad con el Apóstol, pero las cifras que hemos obtenido son diferentes entre los dos territorios, como podemos ver en la tabla 1 que aparece en la página siguiente.

Asturias, donde no se pagaba el Voto, era el único territorio castellano donde Diego ocupaba el segundo lugar, aunque lo perdió en el siglo XVII, en parte por el aumento de los santos franciscanos. En Galicia, aun teniendo el sepulcro del Apóstol, el pago del Voto era general y odiado y eso quizá se traduce en la infrecuencia de Diego o de Jacobo, mientras que era muy alta la suma de dos apóstoles, Juan y Pedro. Diego era muy escaso entre los pleiteantes ante la Real Audiencia y casi se esfuma en el XVII. En los registros parroquiales de Ourense en 1597 no llegaba al 3\% (18,8\% Juan; 14,6\% Pedro, 8,6\% Antonio) y así se mantuvo ${ }^{77}$; en Compostela o en A Coruña, en los bautismos de principios y de mediados del XVII simplemente no aparece como tampoco

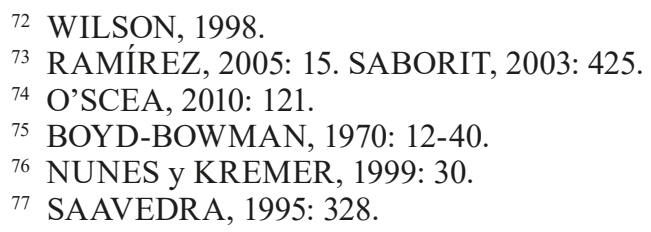


entre los nombres que se imponían a los expósitos que entraban en el torno del Hospital Real de Santiago ${ }^{78}$. Ahora bien, en las partidas de bautismo raras veces figura Jácome, del que tenemos la impresión de que era una forma coloquial: esta denominación se alterna con Diego en las escrituras notariales de la Tierra de Santiago, de modo que en 1600-90 eran Jácome el 63,5\% de los hombres y Diego el 36,5\% en 126 casos, y se invierten en 1635/44 (75,8\% Diego, Jácome $24,2 \%$ en 112 casos), apareciendo la variante Jaime entre los valencianos, aragoneses o catalanes afincados en Compostela, y Jacobo entre otros no castellanos.

Tabla 1. Nombres masculinos en Asturias y Galicia

\begin{tabular}{|l|c|c|c|c|c|c|c|c|}
\hline \multirow{2}{*}{} & \multicolumn{4}{|c|}{ Asturias } & \multicolumn{4}{c|}{ Galicia } \\
\cline { 2 - 10 } & \multicolumn{2}{|c|}{ XVI/2 } & \multicolumn{2}{c|}{ XVII/1 } & \multicolumn{2}{c|}{ XVI/2 } & \multicolumn{2}{c|}{ XVII/1 } \\
\cline { 2 - 9 } & $\mathbf{N}$ & $\mathbf{\%}$ & $\mathbf{N}$ & $\mathbf{\%}$ & $\mathbf{N}$ & $\mathbf{\%}$ & $\mathbf{N}$ & $\mathbf{\%}$ \\
\hline Juan & 30 & 16,2 & 32 & 17,2 & 40 & 20,6 & 43 & 22,6 \\
\hline Diego & $\mathbf{2 1}$ & $\mathbf{1 1 , 4}$ & $\mathbf{1 7}$ & $\mathbf{9 , 1}$ & $\mathbf{1 2}$ & $\mathbf{6 , 2}$ & $\mathbf{2}$ & $\mathbf{1 , 0}$ \\
\hline Pedro & 17 & 9,2 & 20 & 10,7 & 37 & 19,0 & 24 & 12,6 \\
\hline Antonio & 2 & 1,1 & 10 & 5,4 & 9 & 4,6 & 18 & 9,5 \\
\hline Alonso & 19 & 10,3 & 9 & 4,8 & 15 & 7,7 & 12 & 6,3 \\
\hline Francisco & 4 & 2,1 & 11 & 5,9 & 10 & 5,1 & 11 & 5,8 \\
\hline Otros & 92 & 49,7 & 87 & 46,8 & 71 & 36,6 & 80 & 31,6 \\
\hline Total & $\mathbf{1 8 5}$ & $\mathbf{1 0 0}$ & $\mathbf{1 8 6}$ & $\mathbf{1 0 0}$ & $\mathbf{1 9 4}$ & $\mathbf{1 0 0}$ & $\mathbf{1 9 0}$ & $\mathbf{1 0 0}$ \\
\hline
\end{tabular}

En los territorios que pagaban el Voto desde la Edad Media, Diego ocupaba el último lugar en Zamora y León, el cuarto en Ávila y Salamanca y el tercero en Segovia; y en esta y en Salamanca pierde importancia en la primera mitad del XVII, pero se mantuvo en Ávila y creció algo en León y Zamora. Se puede decir que tres apóstoles - Pedro, Juan y Santiago- se reparten la onomástica, junto con los santos franciscanos ${ }^{79}$. Miguel, el arcángel al que Felipe IV quiso elevar a patrono de Castilla, tenían un lugar muy discreto $(2,2 \%)$.

\footnotetext{
78 REY CASTELAO, 2015c: 66-98.

${ }^{79}$ Lo mismo se comprueba en Madrid. GALENDE DÍAZ y GARCÍA TALLARÍN, s. a.: 165-198.
} 
TABLA 2. Nombres masculinos en Castilla y León, zonas pagadoras del Voto

\begin{tabular}{|c|c|c|c|c|c|c|c|c|c|c|}
\hline & \multicolumn{2}{|c|}{ León } & \multicolumn{2}{|c|}{ Zamora } & \multicolumn{2}{|c|}{ Salamanca } & \multicolumn{2}{|c|}{ Segovia } & \multicolumn{2}{|c|}{ Avila } \\
\hline & $\mathbf{N}$ & $\%$ & $\mathbf{N}$ & $\%$ & $\mathbf{N}$ & $\%$ & $\mathbf{N}$ & $\%$ & $\mathbf{N}$ & $\%$ \\
\hline \multicolumn{11}{|c|}{ 1590-99 } \\
\hline Juan & 23 & 18,9 & 16 & 10,1 & 28 & 18,7 & 32 & 17,7 & 33 & 20,1 \\
\hline Diego & 4 & 3,3 & 11 & 6,9 & 14 & 9,3 & 17 & 9,4 & 14 & 8,5 \\
\hline Pedro & 15 & 12,3 & 14 & 8,9 & 20 & 13,3 & 20 & 11,0 & 24 & 14,6 \\
\hline Antonio & 6 & 4,9 & 24 & 15,2 & 13 & 8,7 & 17 & 9,4 & 7 & 4,3 \\
\hline Alonso & 7 & 5,7 & 14 & 8,9 & 10 & 6,7 & 14 & 7,7 & 7 & 4,3 \\
\hline Francisco & 14 & 11,5 & 22 & 13,9 & 19 & 12,7 & 9 & 5,0 & 16 & 9,8 \\
\hline Otros & 53 & 43,4 & 57 & 36,1 & 46 & 30,7 & 72 & 39,8 & 63 & 38,4 \\
\hline Total & 122 & 100 & 158 & 100 & 150 & 100 & 181 & 100 & 164 & 100 \\
\hline \multicolumn{11}{|c|}{$1635-44$} \\
\hline Juan & 20 & 14,0 & 14 & 11,2 & 13 & 10,6 & 35 & 20,3 & 15 & 12,7 \\
\hline Diego & 10 & 7,0 & 10 & 8,0 & 6 & 4,9 & 14 & 8,1 & 10 & 8,5 \\
\hline Pedro & 22 & 15,4 & 9 & 7,2 & 24 & 19,5 & 11 & 6,4 & 9 & 7,6 \\
\hline Antonio & 14 & 9,8 & 7 & 5,6 & 12 & 9,7 & 9 & 5,2 & 8 & 6,8 \\
\hline Alonso & 9 & 6,3 & 7 & 5,6 & 6 & 4,9 & 15 & 8,7 & 8 & 6,8 \\
\hline Francisco & 13 & 9,1 & 20 & 16,0 & 22 & 17,9 & 23 & 13,3 & 19 & 16,1 \\
\hline Otros & 55 & 38,5 & 58 & 46,4 & 40 & 32,5 & 66 & 38,1 & 47 & 39,8 \\
\hline Total & 143 & 100 & 125 & 100 & 123 & 100 & 173 & 100 & 118 & 100 \\
\hline
\end{tabular}

En los territorios que pagaban el Voto desde 1571, después de un largo pleito sentenciado a favor del arzobispo y del cabildo de Santiago en la Chancillería de Granada, las cifras de Diego son peores. En trabajos publicados sobre actas bautismales, en Extremadura a fines del XVI ocupaba el cuarto lugar con un 7,6\% en Mérida y el quinto en Santa Olalla con un 7,2\%, y en Sevilla, se situaba también en el cuarto $-5 \%$ de las frecuencias en el silgo XVII-, siempre muy lejos de Juan o Francisco ${ }^{80}$, y en nuestra muestra, es el quinto en Toledo y es irrelevante en Cuenca, de modo que se podría pensar en cierto rechazo:

${ }^{80}$ BALLESTEROS, 2004: 27-57. PÉREZ GONZÁLEZ, 2017.

Hispania, 2020, vol. LXXX, n. ${ }^{\circ}$ 266, septiembre-diciembre, págs. 783-816, ISSN: 0018-2141, e-ISSN: 1988-8368 https://doi.org/10.3989/hispania.2020.021 
TABLA 3. Nombres masculinos en Castilla La Nueva, zonas pagadoras del Voto

\begin{tabular}{|l|c|c|c|c|c|c|}
\hline \multirow{2}{*}{} & \multicolumn{2}{|c|}{ Toledo 1590-99 } & \multicolumn{2}{c|}{ Toledo 1635-44 } & \multicolumn{2}{c|}{ Cuenca 1590-99 } \\
\cline { 2 - 7 } & $\mathbf{N}$ & $\mathbf{9}$ & $\mathbf{N}$ & $\mathbf{\%}$ & $\mathbf{N}$ & $\mathbf{\%}$ \\
\hline Juan & 32 & 22,4 & 34 & 23,0 & 20 & 23,5 \\
\hline Diego & $\mathbf{8}$ & $\mathbf{5 , 6}$ & $\mathbf{6}$ & $\mathbf{4 , 0}$ & $\mathbf{2}$ & $\mathbf{2 , 3}$ \\
\hline Pedro & 10 & 7,0 & 10 & 6,8 & 14 & 16,5 \\
\hline Antonio & 6 & 4,2 & 6 & 4,0 & 4 & 4,7 \\
\hline Alonso & 11 & 7,7 & 10 & 6,7 & 2 & 2,3 \\
\hline Francisco & 11 & 7,7 & 19 & 12,8 & 13 & 15,3 \\
\hline Otros & 65 & 45,4 & 63 & 42,6 & 30 & 35,3 \\
\hline Total & $\mathbf{1 4 3}$ & $\mathbf{1 0 0}$ & $\mathbf{1 4 8}$ & $\mathbf{1 0 0}$ & $\mathbf{8 5}$ & $\mathbf{1 0 0}$ \\
\hline
\end{tabular}

Las diócesis más contestatarias contra el Voto - Burgos, Palencia, Osma, Calahorra y Sigüenza - protagonizaron en estos años el llamado Pleito Grande, sentenciado a su favor en 1593 y 1628 al haber basado su defensa el licenciado Lázaro González de Acevedo, abogado de los pueblos de aquellos obispados, en contradecir las tradiciones jacobeas. En 87 casos de Osma y Sigüenza, Diego era el 9,1\% y en la actual Rioja, más del 10\%, quizá porque albergaban lugares emblemáticos del patronato jacobeo, como el cerro de Clavijo, en tanto que en Burgos ocupaba el quinto lugar y pasó al cuarto, era el último en Palencia y descendió, por lo que no se constata una especial reacción, salvo que le agradecieran al Apóstol su victoria sobre el cabildo y arzobispo compostelanos...; creemos, más bien, que el nombre Diego no se asociaba con Santiago. Ver tabla 4 en la siguiente página.

El dominio mariano se constata entre las mujeres: en 162 casos, a fines del siglo XVI, María es el 24,7\% y Ana el 6,2\%, y en 135 del XVII, el 19,2\% y Ana el 7,4\%; pero Teresa apenas aparece, lo que llama la atención en medio de la importancia de Catalina (14,2\%/10,4\%) e Isabel (13\% y 5,9\%). El efecto del patronato no ayudó a Teresa a hacerse un hueco en la onomástica, quizá por falta de tiempo para arraigar.

Tanto en el caso de Teresa como en el de Santiago se ha hecho hincapié en la importancia de la predicación, sin duda fundamental para captar devotos en una sociedad mayoritariamente analfabeta y piadosa como la castellana de aquel tiempo. En las polémicas del patronato proliferaron los sermones, publicados muchos de ellos, y los comentaristas de un lado y otro anotaron el éxito que alcanzaban entre su auditorio, sin que se sepa muy bien quién lo componía. Pero no se tiene en cuenta que todos los párrocos de la Castilla pagadora del 
TABla 4. Nombres masculinos en Castilla, zonas no pagadoras del Voto

\begin{tabular}{|c|c|c|c|c|c|c|c|c|c|c|c|c|}
\hline & \multicolumn{2}{|c|}{$\begin{array}{c}\text { Burgos } \\
1590-99\end{array}$} & \multicolumn{2}{|c|}{$\begin{array}{c}\text { Burgos } \\
1635-44\end{array}$} & \multicolumn{2}{|c|}{$\begin{array}{c}\text { Palencia } \\
1590-99\end{array}$} & \multicolumn{2}{|c|}{$\begin{array}{c}\text { Palencia } \\
1635-44\end{array}$} & \multicolumn{2}{|c|}{$\begin{array}{c}\text { Rioja } \\
\text { 1590-99 }\end{array}$} & \multicolumn{2}{|c|}{$\begin{array}{c}\text { Rioja } \\
1635-44\end{array}$} \\
\hline & $\mathbf{N}$ & $\%$ & $\mathbf{N}$ & $\%$ & $\mathbf{N}$ & $\%$ & $\mathbf{N}$ & $\%$ & $\mathbf{N}$ & $\%$ & $\mathbf{N}$ & $\%$ \\
\hline Juan & 31 & 23,0 & 35 & 23,0 & 25 & 21,7 & 33 & 26,8 & 30 & 21,0 & 36 & 22,1 \\
\hline Diego & 5 & 3,7 & 14 & 9,5 & 6 & 5,2 & 4 & 3,2 & 16 & 11,1 & 21 & 12,8 \\
\hline Pedro & 25 & 18,5 & 18 & 12,1 & 14 & 12,2 & 12 & 9,8 & 15 & 14,5 & 27 & 16,6 \\
\hline Antonio & 5 & 3,7 & 3 & 2,0 & 9 & 7,8 & 8 & 6,5 & 4 & 2,8 & 2 & 1,2 \\
\hline Alonso & 10 & 7,4 & 9 & 6,1 & 6 & 5,2 & 4 & 3,2 & 2 & 1,4 & 2 & 1,2 \\
\hline Francisco & 20 & 14,8 & 15 & 10,1 & 12 & 10,4 & 18 & 14,6 & 18 & 12,6 & 27 & 16,6 \\
\hline Otros & 39 & 28,9 & 54 & 36,5 & 43 & 37,4 & 44 & 35,8 & 58 & 40,6 & 48 & 29,4 \\
\hline Total & 135 & 100 & 148 & 100 & 115 & 100 & 123 & 100 & 143 & 100 & 163 & 100 \\
\hline
\end{tabular}

Voto estaban obligados cada año a pagar ellos mismos el Voto si tenían tierras, a recontar a todos los feligreses que debían pagarlo, una tarea que les desagradaba porque generaba tensiones con quienes ya pagaban diezmos y primicias; a anunciar en sus iglesias la obligación de pagar la renta y a leer las condenas que comportaba su impago, lo que seguramente tendría un efecto negativo entre los feligreses. Por otro lado, los obispos y cabildos castellanos y las órdenes religiosas eran contrarios a esa renta, por lo que probablemente sus predicaciones no contribuirían a hacerla popular. Si a esto se añade la actitud de la monarquía, intentando mandar al Apóstol a la reserva, no es difícil deducir que no era popular entre las gentes del común, como tampoco lo era en Portugal por parecidas razones.

\section{REFLEXIONES FINALES Y CONCLUSIONES}

La historiografía anglosajona es la que hace años puso el tema del patronato en el plano político, al centrar el análisis en la intervención de Olivares y Quevedo y en textos de la cultura política de aquel período, y fue John Elliott (1986) quien vinculó la polémica con la identidad española, calificando de provocación la proclamación de Teresa hecha en Zaragoza en el contexto de la Unión de $\mathrm{Armas}^{81}$. Los estudiosos franceses e italianos lo han vinculado con la religión y con las relaciones entre la monarquía y la Iglesia. La bibliografía

\footnotetext{
${ }^{81}$ ELLIOTT, 1986: 327-328.
} 
hispana en general ha interpretado la polémica como una manifestación de las devociones particulares de los reyes, de sus validos y de las Cortes, interviniendo el papa solo para refrendar decisiones ajenas sin implicarse en algo que era privativo de un país, pero que no era ni general, ni sustancial, ni siquiera identitario. Esto último es importante porque unos se refieren a la Corona de Castilla, otros hablan de España e, incluso, de la nación española, y porque la carga identitaria de Santiago o de Teresa era antitética: conviene recordar que Santiago había colaborado a la unificación territorial cortando cabezas de moros y de indios, y que los santiaguistas se presentaban como garantes de la unión a través de la común tradición apostólica, por lo que el significado de Teresa como símbolo de la unión, no solo tuvo que construirse en su época, sino en la bibliografía.

En ese sentido, se ha dado prioridad a Teresa, la recién llegada, que, en general, aparece como moderna y española. Quizá Américo Castro fue el único que la tachó de medievalizante, elevada por los Felipes por su centralismo cortesano - Compostela estaba lejos_- la exaltación de la «casta triunfante», la falta de objetivos de conquista y un gobierno administrativo-político, coincidente con el reformismo inicial de Olivares, sin ser moderna la santa, sino representante de «la ociosidad mendicante» ${ }^{82}$. Pero los autores posteriores defendieron lo contrario. T. D. Kendrik (1960) la consideraba moderna y popular ${ }^{83}$. López Estrada (1984) valora su capacidad de defender a la monarquía de un modo nuevo, reformista y renovador, no en vano era una mujer caracterizada por su actividad, novedad, gobierno y autoridad ${ }^{84}$. Márquez Villanueva (2004) la incluyó en los «mitos de relevo» y en la obsesión colectiva por obtener protección mediante una idea nueva y de renovación de las estructuras mentales. Dando un paso más allá, bastante discutible, Sandra Chaparro $(2009,2012)$ introduce la clave de género, la capacidad de Teresa para moldear conductas basadas en la fe, la lealtad, reciprocidad, igualdad o la templanza, en tanto que era una mística contemplativa pero activa, por lo que su elección equivalía a suscribir el valor del trabajo compatible con el rezo y la meditación, las cosas sencillas y la familia ${ }^{85}$. En parte en la misma línea, Erin Rowe considera nueva y contemporánea a Teresa, útil como guía para los problemas del siglo XVII, de modo que sus partidarios reconceptualizaron la nación al priorizar lo moderno. Modernidad y género son sin duda dos anacronismos.

Por lo que se refiere a su adscripción político-territorial, Teófanes Egido, el mejor conocedor de la santa, habla siempre de ella como «castellana», y por

\footnotetext{
${ }^{82}$ CASTRO, 1929; 1948: 390-396, 399.

83 KENDRICK, 1960: 61, 62, 69.

${ }^{84}$ LÓPEZ ESTRADA, 1984: 654.

${ }^{85}$ CHAPARRO MARTÍNEZ, 2009: 189-190.
} 
ello, como sucedía con los «santos naturales» obligada a proteger a su tierra ${ }^{86}$. López Estrada la hace española, por lo que defendería a los españoles frente a enemigos externos y a herejes ${ }^{87}$, en tanto que Giuliana Di Febo añade la faceta de Teresa como santa de la raza, la imagen de una mujer fortis y con linaje, y de la hispanidad católica triunfante, con atributos masculinos y femeninos ${ }^{88}$. La posición más radical es la de Erin Rowe, que si bien une a Santiago y Teresa bajo el término «españolidad», centra en la elección de la santa el cambio político, espiritual e ideológico que alteraba la comprensión tradicional de la nación española al interrumpir un relato, el final de la Reconquista, dando pie a discutir el carácter de España como «nación» y el papel de la religión en su construcción desde su propio origen; en el debate se emplearon términos diferentes para designarla - monarquía española, Españas, Hispania, Corona de Castilla - y se atribuyeron a cada santo rasgos para definirla ${ }^{89}$. De nuevo nos encontramos con un anacronismo.

Igual atención que la personalidad de los compatronos ha generado el procedimiento de su elección, por su indudable lectura política. Américo Castro o José Antonio Maravall discutieron la capacidad de las Cortes para ello, cuando estas no tenían competencia ni representaban a todo el reino ${ }^{90}$, pero sobre todo ha sido objeto de análisis por Irving A. A. Thompson, para quien, Cortes y rey cuestionaron la supremacía papal. Para esto fue preciso definir el concepto de patronato, ya que, según los teresistas, para elegir a un intercesor o protector no hacía falta permiso papal, mientras los santiaguistas lo consideraban una concesión de Cristo. Los teresistas confundían la voluntad de las Cortes con la de España y otorgaban a estas la capacidad de intervenir en materia eclesiástica y de obligar al clero a acatar su decisión, al no estar exento de las leyes civiles y políticas, en tanto que era el rey quien debía autorizar la novedad. Mientras que los santiaguistas defendían que la autoridad real estaba limitada por la eclesiástica y la papal, superiores en lo espiritual y religioso ${ }^{91}$. Sin duda, esta cuestión era relevante, como lo demuestra que en 1630 el papado reguló la fórmula de elección en su favor ${ }^{92}$, pero, como hemos visto en el caso portugués, no necesariamente se obedecía al papa.

Otra dimensión política es la intervención de Olivares a favor de Teresa de Ávila, más intuida que documentada. Erin Rowe, redondeando lo sugerido por autores ya mencionados, incide en que la existencia de dos patronos

\footnotetext{
${ }^{86}$ EGIDO, 2003:103.

${ }^{87}$ LÓPEZ ESTRADA, 1984: 661.

${ }^{88}$ DI FEBO, 1987: 78-80.

89 ROWE, 2005; 2006a; 2006b; 2011.

90 MARAVALL, 2001: 293, 361.

91 THOMPSON, 2008: 293.

92 SERRANO MARTÍN, 2018: 75.
}

Hispania, 2020, vol. LXXX, n. ${ }^{\circ}$ 266, septiembre-diciembre, págs. 783-816, ISSN: 0018-2141, e-ISSN: 1988-8368 https://doi.org/10.3989/hispania.2020.021 
simbolizaba los peligros de la autoridad plural — el rey y el valido — y que la hostilidad hacia Teresa lo era a Olivares y al valimiento. De mayor relieve es que, momentáneamente al menos, el interés de las elites en una nueva representación espiritual, reflejaría profundas transformaciones y la cambiante situación política en Europa, que generaban inestabilidad de la identidad y una crisis general entre los castellanos ${ }^{93}$.

En nuestra opinión, hay varios problemas de enfoque. En primer lugar, no suele tenerse en cuenta que los territorios no castellanos de la monarquía no entraron en el debate, revelando que el patronato de Santiago o de Teresa era cosa de Castilla. Sí lo hicieron los portugueses por cuanto el cambio ponía en cuestión sus propios orígenes y la identidad que estaban construyendo a cuenta de las tradiciones del Apóstol Santiago, mientras Castilla ponía en riesgo la suya propia. En segundo lugar, definiciones de personalidad, procedimientos de elección, acciones políticas y campañas de propaganda no lograron ir más allá de los medios cortesanos y elitistas, de modo que no se detectan reacciones populares al cambio de patrono ni indicios de devoción a la nueva patrona, en lo que seguramente afectó la brevedad de sus dos períodos; como tampoco de devoción al patrón tradicional, cuyo solo nombre evocaba negativamente el pago anual del Voto de Santiago en casi todos los territorios de la Corona de Castilla y en el Norte de Portugal.

Finalmente, se ha dado tanta importancia a Teresa que se olvida que fue la perdedora, que los cambios de patronato entraban en cierta normalidad — antes Francia, luego Portugal, hicieron los suyos-y que, en plena crisis territorial por la separación de Portugal y la rebelión de Cataluña, se intentó recurrir a otro patrón, San Miguel, un arcángel no menos guerrero que Santiago. Volviendo a lo primero, en realidad fue Santiago el vencedor: T.D. Kendrick lo atribuye al miedo a enfadarlo, es decir, se remite al temor ancestral al poderoso, y lo mismo dice Erin Rowe, para quien atacar a Santiago, a pesar de estar en descrédito, podría llevar a la destrucción con la que amenazaban sus partidarios $^{94}$. López Estrada adjudicó el triunfo del Apóstol a «acciones políticas de fuerza suficiente como para ganar la partida al mismo rey», sin especificar cuáles ${ }^{95}$. Francisco Vivar lo hizo al error político que suponía un patronato doble cuando era preciso unir a los territorios a través de la religión y dar impulso al imperio revitalizando los mitos nacionales. En tanto que para Márquez Villanueva ${ }^{96}$, Santiago venció porque simbolizaba un arcaico sentimiento de identidad política y religiosa, y porque el debate fue más guerrillero que teológico, como ya hemos dicho en publicaciones anteriores.

\footnotetext{
93 ROWE, 2005; 2006a: 416; 2006b: 721.

94 ROWE, 2011.

${ }^{95}$ LÓPEZ ESTRADA, 1984: 670.

96 MÁRQUEZ VILLANUEVA, 2004: 341-346.
}

Hispania, 2020, vol. LXXX, n. ${ }^{\circ}$ 266, septiembre-diciembre, págs. 783-816, ISSN: 0018-2141, e-ISSN: 1988-8368 https://doi.org/10.3989/hispania.2020.021 
En varias ocasiones desde nuestra tesis (1984) hemos defendido que la victoria del Apóstol era la más conveniente en el ambiente conservador y celoso de «las glorias de España» cuando el imperio daba signos de decadencia y, sobre todo, defendemos que respondió a intereses sociales y económicos de baja altura, más que a complejas teorías político-religiosas. Las instituciones y personas implicadas y sus cambios de posición revelan el interés en mantener la esencia histórica de linajes, ciudades, regiones, órdenes militares, etc. ${ }^{97}$. Paradójicamente esto vale también para explicar la intervención de los portugueses a favor de Santiago. La identidad de quienes dirigieron las operaciones de anulación del compatronato - arzobispos y cabildos compostelanos y bracarenses - revelan a su vez los enormes beneficios que reportaba la renta del Voto de Santiago, empleados para asegurar fidelidades y voluntades - fue el caso de Quevedo- - para pagar gestiones en la Corte y en Roma y para financiar excelentes campañas de propaganda. Esto explica también que durante los dos episodios del compatronato, los delegados reales siguieran luchando en Roma por la restauración de la tradición jacobea en la liturgia tridentina, lo que se consiguió en 1630, sin que lo uno o lo otro contribuyese a mejorar la imagen popular de Santiago.

\section{Bibliografía}

Acosta Lobo, Antonio, Origens do Sebastianismo, Alfagride, Texto editores, 2012.

Almeida, João Miguel y Matos Ferreira, António, Protagonistas, motivações e dinámicas sociais no contexto Ibérico, Lisboa, Centro de Estudos de História Religiosa, 2012.

Álvarez Gila, Óscar, Angulo Morales, Alberto y Ramos Martínez, Jon Ander (eds.), Devoción, paisanaje e identidad. Las cofradías y congregaciones de naturales en España y en América (siglos XVI-XIX), Bilbao, Universidad del País Vasco, 2014.

Álvarez Junco, José y De La Fuente, Gregorio, El relato nacional: Historia de la historia de España, Madrid, Marcial Pons, 2017.

Ashton, Gail, The generation of identity in Late Medieval Hagiography. Speaking in the Saint, Londres, Routledge, 2000.

Ballesteros Díez, José Antonio, «Onomástica y mentalidades en el siglo XVI», Espacio, Tiempo y Forma. Serie IV. Historia Moderna, 17 (Madrid, 2004): 27-57.

Billy, Pierre-Henri, «Hagiographie et onomastique», en Sébastien Nadiras (ed.), Nomes des lieux, noms de personnes, Pierreffite-sur-Seine, Publications des Archives Nationales, 2018.

Borges, Alexandre, Histórias secretas de Reis de Portugal, Alfagride, Casa das Letras, 2012.

\footnotetext{
${ }^{97}$ REY CASTELAO, 1985.
}

Hispania, 2020, vol. LXXX, n. ${ }^{\circ}$ 266, septiembre-diciembre, págs. 783-816, ISSN: 0018-2141, e-ISSN: 1988-8368 https://doi.org/10.3989/hispania.2020.02 
Bouza, Fernando, Imagen y propaganda. Capítulos de historia cultural del reinado de Felipe II, Madrid, Akal, 1998.

Boyd-Bowman, Peter, «Los nombres de pila en México desde 1540 hasta 1950», Nueva Revista Filología Hispánica, XIX (México, 1970): 12-48.

Brandao, Fray Antonio, Terceira Parte da Monarchia Lusitana, Lisboa, Pedro Crasbeeck impresor, 1632.

Brito, Fray Bernardo, Monarchia Lusitana Parte Primeira, Alcobaça, Alexandre de Siqueira e Antonio Alvares impresores, 1597.

Brito, Fray Bernardo, Segunda Parte da Monarchia Lusitana, Lisboa, Pedro Crasbeeck impresor, 1607.

Buescu, Ana Isabel, «Vinculos de memoria: Ourique e a fundaçâo do reino», en Yvette Kace Centeno (coord.), Portugal, Mitos revisitados, Lisboa, Salamandra, 1993: 9-50.

Cabrillana Ciézar, Nicolás, Santiago Matamoros: historia e imagen, Málaga, Diputación de Málaga, 1999.

Cacegas, Frei Luis de, Vida de dom Frei Bartolomeu dos Martyres... arzobispo de Braga, Viana, Nicolás Carvalho, 1619.

Caliò, Tommaso, Duranti, Maria y Michetti, Raimondo (dirs.), Italia Sacra. Le tradizioni agiografiche regionali, Roma, Viella, 2002.

Calvo Domínguez, Marcelina, «O culto de Santiago e a arte portuguesa da Idade moderna», en Marcelina Calvo Domínguez (coord.), Santiago: A Esperanza, Santiago de Compostela, Xunta de Galicia, 1999: 193-199.

Campos y Fernández de Sevilla, Francisco Javier, La mentalidad en Castilla la Nueva en el siglo XVI: religión, economía y sociedad, según las "Relaciones topográficas» de Felipe II, El Escorial, EDES, 1986.

Campos Moreno, Araceli y Cardaillac, Luis, Indios y cristianos: cómo en México el Santiago español se hizo indio, Jalisco, Colegio de Jalisco, 2007.

Capela, José Viriato, Os votos de Santiago no Arcebispado de Braga, Braga, Universidade de Braga, 1979.

Cardaillac, Luis, Santiago Apóstol. El santo de los dos mundos, Jalisco, Colegio de Jalisco, 2002.

Cardim, Pedro, A História: Entre Memória e Invenção, Lisboa, Publicações Europa-América, 1998.

Cardim, Pedro, «Los portugueses frente a la monarquía hispánica», en Bernardo J. García García y Antonio Alvarez-Ossorio (eds.), La monarquía de las naciones: patria, nación y naturaleza en la monarquía de España, Madrid, Fundación Carlos de Amberes, 2004: 355-384.

Cardim, Pedro, «Una Restauraçâo visual? Cambio dinástico y uso de la imagen en el Portugal del siglo XVII», en Joan Lluís Palos y Diana Carrió (eds.), La historia imaginada. Construcciones visuales del pasado en la Edad Moderna, Madrid, Centro de Estudios Europa Hispánica, 2008: 185-206.

Carvalho, Joaquim (ed.), Religion and Power. Conflict and Convergence, Pisa, Pisa, University Press, 2007.

Castejón y Fonseca, Diego de, Primacía de la Santa Iglesia de Toledo, su origen, sus medras, sus progressos...: defendida contra las impugnaciones de Braga, Madrid, Diego Díaz de La Carrera, 1645.

Hispania, 2020, vol. LXXX, n. ${ }^{\circ}$ 266, septiembre-diciembre, págs. 783-816, ISSN: 0018-2141, e-ISSN: 1988-8368 https://doi.org/10.3989/hispania.2020.021 
Castro, Américo, Santa Teresa: y otros ensayos, Santander, Historia Nueva, 1929.

Castro, Américo, La realidad histórica de España, México, Editorial Porrua, 1948.

Chaparro Martínez, Sandra, «La rueca y la espada: El patronato de Santa Teresa o la mujer como metáfora política», en Pilar Pérez Cantó (ed.), De la democracia ateniense a la democracia paritaria, Barcelona, Icaria, 2009: 43-60.

Chaparro Martínez, Sandra, Providentia: el discurso político providencialista espanol de los siglos XVI y XVII, Madrid, Universidad de Comillas, 2012.

Chapman, Alison, Patrons and Patron Saints in Early Modern English Literature, Londres, Routledge, 2013.

Chaves, Luís, «Influxo de Nossa Senhora na formação da alma nacional», en Fernando de C. P. Lima, A Virgem e Portugal, Porto, Ed. Ouro, 1967, vol. 1: 57-87.

Choy, Emilio, De Santiago Matamoros a Santiago Mataindios, Lima, Universidad de San Marcos, 1985.

Christian, William A., Religiosidad local en la España de Felipe II, Madrid, Nerea, 1991.

Civil, Pierre, «De Saint-Jacques Matamore à Saint-Ignace de Loyola: stratégies de l'image des saints face à l'altérité religieuse (Espagne, XVIe-XVIIe siècles)», en Agustín Redondo (dir.), Les représentations de l'autre dans l'espace Ibérique et Ibéro-Américain, París, Sorbonne, 1993, vol. II: 75-98.

Clarke, Peter y Claydon, Tony, Saints and sanctity, Rochester, Boydell \& Brewer, 2011.

Cruz Valdovinos, José Manuel, «Santiago, patrón de España», en Santiago. La esperanza, Santiago de Compostela, Xunta de Galicia, 1999: 123-139.

Da Costa, Avelino de Jesús, Origem e evoluçao do culto de Nossa Senhora da Conceiçâo em Portugal, Braga, s. e., 1964.

Da Cunha i Silva, Rodrigo, Tractatus de Primatu bracharensis ecclesia in universa Hispania, Braga, Joannis Roderici, 1632.

Da Cunha i Silva, Rodrigo, Primeira Parte de Historia Eclesiástica dos Arcebispos de Braga, e dos santos e varoes, Braga, Manuel Cardoso, 1634.

Di Febo, Giuliana, La Santa de la Raza. Un culto barroco en la España franquista, Barcelona, Icaria, 1987.

Domínguez García, Javier, Del Apóstol Matamoros a Yllapa Mataindios. Dogmas e ideologías medievales en el (des) cubrimiento de América, Salamanca, Universidad de Salamanca, 2008.

Dos Santos, Armando A., O culto de Maria Imaculada na tradição e na história de Portugal, Porto/Sao Paulo, Ed. Art Press, 1996.

Egido, Teófanes, «Religiosidad "popular" y Cortes tradicionales de Castilla», en María Jesús Buxó, Salvador Rodríguez Becerra y León Carlos Álvarez y Santaló (eds.), La religiosidad popular, Vida y muerte, Barcelona, Anthropos, 2003, vol. 2: 96-110.

Elliott, John H., The Count-Duke of Olivares, Yale, Yale University Press, 1986.

Fandiño Fuentes, Rafael, «La translatio de santos mártires de Braga a Compostela. Reflexiones sobre el capítulo I, 15 de la Historia Compostelana», Cuadernos de Estudios Gallegos, 130 (Santiago de Compostela, 2017): 119-140.

Faria i Sousa, Manuel de, Epitome de las historias portuguesas: dividido en cuatro partes, Madrid, Francisco Martínez impresor, 1628. 
Feros Carrasco, Antonio «Por Dios, por la patria y el rey: el mundo político en tiempos de Cervantes», en Antonio Feros y Juan E. Gelabert (dirs.), España en tiempos del Quijote, Madrid, Taurus, 2004: 61-96.

Ferreira Fernandes, Isabel Cristina, «Iconografía da guerra santa no territorio portugués», en Carlos de Ayala Martínez, Patrick Henriet y J. Santiago Palacios Ontalva (eds.), Orígenes y desarrollo de la guerra santa en la Península Ibérica. Palabras e imágenes para una legitimación (siglos X-XIV), Madrid, Casa de Velázquez, 2016: 296-310.

Floristán Imízcoz, Alfredo, «“Ex hostibus et in hostes”. La configuración de identidades colectivas como confrontación múltiple: Navarra entre Sobrarbe y Cantabria, siglos XVI y XVII», en Bernardo J. García García y Antonio Álvarez-Ossorio (eds.), La monarquía de las naciones. Patria, nación y naturaleza en la Monarquía de España, Madrid, Fundación Carlos de Amberes, 2004: 327-354.

Floristán Imízcoz, Alfredo, «Polémicas historiográficas y confrontación de identificaciones colectivas en el siglo XVII: Navarra, Aragón, Vasconia», Pedralbes, 27 (Barcelona, 2007): 59-82.

Franco, José Eduardo, A primeira história de Portugal e a sua função política, Lisboa, Roma editora, 2000.

Galende Díaz, Juan Carlos y García Gallarín, Consuelo, «Onomástica y deonomástica del siglo XVII», en $V$ Jornadas Científicas sobre Documentación en España e Indias durante el siglo XVII, Madrid, Universidad Complutense, s. a.: 165-182.

García Fernández, Máximo, «El recurso al santoral en Castilla del Barroco a la Ilustración», Hispania Sacra, 50 (Madrid, 1990): 132-173.

García Hernán, Enrique, «Construcción de las historias de España en los siglos XVII y XVIII», en Ricardo García Cárcel (coord.), La construcción de las Historias de España, Madrid, Marcial Pons, 2004: 127-194.

García Hernán, Enrique, «La España de los cronistas reales en los siglos XVI y XVII», Norba, 19 (Cáceres, 2006): 125-150.

Gatter, Olivia, «Saint Teresa of Avila as an Intercessor», http://ctl.w3.uvm.edu/omeka/ files/original/db889ddf92ceb4cfebb0d8c9cdab5c5c.pdf (última consulta, 31/01/2019).

Gómez López, Consuelo, «El apóstol Santiago y la Corte: mentalidad, imagen y promoción artística», en Santiago y la Monarquía de España (1504-1788), Santiago de Compostela, Sociedad Estatal de Conmemoraciones Culturales, 2004: 87-100.

González Lopo, Domingo Luis, «La devoción a Santiago Apóstol en la Galicia de los siglos XVII y XVIII», Tui Museo y Archivo Histórico Diocesano, 8 (Tui, 1994): 53-63.

González Lopo, Domingo Luis, «Evolución del asociacionismo religioso», Obradoiro de Historia Moderna, 5 (Santiago de Compostela, 1996): 157-192.

Herbers, Klaus, Política y veneración de los santos en la Península Ibérica. Desarrollo del Santiago político, Poio, Fundación Cultural Rutas del Románico, 1999.

Kagan, Richard L., Los cronistas y la Corona: La política de la historia en la España medieval y moderna, Madrid, Marcial Pons, 2010.

Kendrick, Thomas Downing, Saint James in Spain, Londres, Methuen \& Co. Ltd., 1960.

Lara Ródenas, Manuel José de, La muerte barroca. Ceremonia y sociabilidad funeral en Huelva durante el siglo XVII, Huelva, Universidad de Huelva, 1999.

Hispania, 2020, vol. LXXX, n. ${ }^{\circ}$ 266, septiembre-diciembre, págs. 783-816, ISSN: 0018-2141, e-ISSN: 1988-8368

https://doi.org/10.3989/hispania.2020.021 
Le Gall, Jean-Marie, Le mythe de Saint Denis entre Renaissance et Révolution, París, Champ Vallon, 2007.

Linares, Lidwine, «Territoire et représentations. La variété des figures de saint Jacques dans quelques chroniques locales du Siècle d'Or», en François Delpech (ed.), L'imaginaire du territoire en Espagne et au Portugal (XVIe-XVIIe siècles), Madrid, Casa de Velázquez, 2008: 123-135.

Lopes Alves, José, A batalha de Ourique 25 de Julho de 1139, certezas e congeminações do pensamento acumulado até primórdios do século XXI, s. 1., Europress, 2008.

López Estrada, Francisco, «Cohetes para Teresa: la relación de 1627 sobre las fiestas de Madrid por el Patronato de España de Santa Teresa de Jesús y la polémica sobre el mismo», en Teófanes Egido (ed.), Congreso internacional Teresiano, Salamanca, Universidad de Salamanca, 1984: 654-670.

López López, Roberto Javier, «La pervivencia de un mito bélico. La imagen de Santiago caballero», en David González Cruz (ed.), Religión y conflictos bélicos en Ibero-América, Sevilla, Universidad Internacional de Andalucía, 2008: 41-73.

Magalhães Godinho, Vitorino, Portugal: a emergência de uma nação (Das raízes a 1480), Lisboa, Calibri, 2004.

Maravall, José Antonio, Estudios de historia del pensamiento español, Madrid, Ed. de Cultura Hispánica, 2001.

Marques, José, «O culto de S. Tiago no Norte de Portugal», Lusitania Sacra, 4 (Lisboa, 1992): 99-148.

Márquez Villanueva, Francisco, Santiago, la trayectoria de un mito, Barcelona, Ediciones Bellaterra, 2004.

Martínez Gil, Fernando, Muerte y sociedad en la España de los Austrias, Cuenca, Universidad de Castilla-La Mancha, 2000.

Mattoso, José, Identificação de um país. Ensaio sobre as origens de Portugal 10961325, Lisboa, Editorial Estampa, 1988.

Méndez Martínez, Gonzalo, «Santiago en la toponimia americana. Relación de topónimos vinculados a Santiago en América», Catálogo de la Exposición, Santiago y América, Santiago de Compostela, Xunta de Galicia, 1993: 93-117.

Merluzzi, Manfredi, Devozioni, pratiche e immaginario religioso, Roma, editorial, 2009.

Morgan, Ronald J., Spanish-American saints and the rhetoric of identity, 1600-1800, Tucson, University of Arizona Press, 2002.

Nale, Sara T., God in La Mancha: Religious reform and the people of Cuenca, 15001650, Baltimore, Johns Hopkins University Press, 2008.

Nieto Alcalde, Víctor y García Morales, María Victoria, «Santiago y la monarquía española: orígenes de un mito de Estado», en José Manuel García Iglesias (coord.), Santiago y la Monarquía de España (1504-1788), Madrid, Sociedad Española de Conmemoraciones Culturales, 2004: 33-52.

Nunes, Naidea N. y Kremer, Dieter, Antroponímia primitiva da Madeira e repertório onomástico histórico da Madeira (séculos XV e XVI), Tubingen, Niemeyer, 1999.

O’Scea, Ciaran, «Nominación de los irlandeses en España, rechazo y asimilación, 1600-1680», en Gregorio Salinero e Isabel Testón (eds.), Un juego de engaños: 
movilidad, nombres y apellidos en los siglos XV a XVIII, Madrid, Casa de Velázquez, 2010: 121-138.

Oliveira Martíns, Alcina Manuela, Os Votos de S.Tiago no norte de Portugal (sécs. XII-XV), Santiago de Compostela, Xunta de Galicia, 1998.

Peinado Guzmán, José Antonio, «Orígenes y desarrollo de la fiesta de la Inmaculada Concepción», Advocaciones marianas (San Lorenzo de El Escorial, 2012): 75-90.

Pérez Costanti, Pablo, Notas viejas galicianas, A Coruña, Boreal, 2008.

Pérez González, Carlos, «Juan de Mariana y su valoración de las crónicas medievales, en lo relativo a la venida de Santiago a España, en el "De adventu Beati Iacobi apostoli in Hispaniam"», en Maurilio Pérez González (coord.), Congreso Internacional sobre Humanismo y Renacimiento, León, Universidad de León, 1998, vol. I: 537-547.

Pérez González, Silvia (dir.) y Arboleda Goldaracena, Juan Carlos (coord.), $C X X I I$ Reglas de Hermandades y cofradias andaluzas, siglos XVI y XVII, Huelva, Universidad de Huelva, 2017.

Péricard-Méa, Denise, Le matamore - mythe, images et réalités, Cahors, Editions La Louve, 2011.

Ramírez Sábada, José Luis, La Onomástica en Navarra y su relación con la de España, Pamplona, Universidad Pública de Navarra, 2005.

Räsänen, Marika, Hartmann, Gritje y Richards, Earl Jeffrey (eds.), Relics, Identity, and Memory in Medieval Europe, Turnhout, Brepols, 2016.

Rey Castelao, Ofelia, La historiografía del Voto de Santiago. Recopilación crítica de una polémica histórica, Santiago, Universidad de Santiago, 1985.

Rey Castelao, Ofelia, El Voto de Santiago. Claves de un conflicto, Santiago de Compostela, Xunta de Galicia, 1993.

Rey Castelao, Ofelia, «Historia e imaginación: la fiesta ficticia», en Manuel Núñez (ed.), El rostro y el discurso de la fiesta, Santiago de Compostela, Universidad de Santiago de Compostela, 1994: 185-196.

Rey Castelao, Ofelia, «La disputa del patronazgo de la Monarquía: ¿Santiago o Santa Teresa?», en José Martínez Millán y Maria Antonietta Visceglia (eds.), La Monarquía de Felipe III: la Casa del Rey, Madrid, Fundación Mapfre, 2007-2008, vol. 1: 227-246.

Rey Castelao, Ofelia, Los mitos del Apóstol Santiago, Vigo, Nigratrea, 2008.

Rey Castelao, Ofelia, «Teresa, patrona de España», Hispania Sacra, 136 (Madrid, 2015a): 531-575.

Rey Castelao, Ofelia, «Los moriscos y el voto de Santiago», Iacobus, revista de estudios jacobeos, 33-34 (Carrión de los Condes, 2015b): 235-248.

Rey Castelao, Ofelia, «Parrains et marraines en Galice aux XVIe-XIXe siècles: Le diocèse de Saint-Jacques-de-Compostelle», en Guido Alfani, Vincent Gourdon e Isabelle Robin (dirs.), Le parrainage en Europe et en Amérique Pratiques de longue durée (XVIe-XXIe siècle), Bruselas, Peter Lang, 2015c: 69-98.

Rey Castelao, Ofelia, «Las ciudades sin historia o la cronística pobre del Noroeste castellano, 1580-1650», en Roberto López Vela, Susana Truchuelo García y Marina Torres Arce (eds.), Civitas: expresiones de la ciudad en la Edad Moderna, Santander, Universidad de Cantabria, 2015d: 53-72.

Rey Castelao, Ofelia, «El Apóstol Santiago y las tradiciones jacobeas en el teatro» en Inmaculada Arias de Saavedra, Esther Jiménez y Miguel Luis López-Guadalupe 
(eds.), Subir a los altares. Modelos de santidad en la Monarquía Hispánica (siglos XVI-XVIII), Granada, Universidad, 2018: 379-399.

Rey Castelao, Ofelia, «Los mitos jacobeos en el discurso histórico-religioso barroco», en José Jaime García Bernal y Clara Bejarano (eds.), Memoria de los orígenes: el discurso histórico-eclesiástico en el mundo moderno, Sevilla, Universidad, 2019: 475-492.

Rodríguez Puértolas, Julio, «Las relaciones hispano-portuguesas en torno a 1492: una historia de encuentros y desencuentros», en Ana María Carabias Torres (ed.), Las relaciones entre Portugal y Castilla en la época de los descubrimientos y la expansión colonial, Salamanca, Universidad de Salamanca, 1994: 63-76.

Rowe, Erin K., Disrupting the Republic: Santiago, Teresa de Jesús, and the Battle for the Soul of Spain, 1617-1630, Baltimore, The John Hopkins University, 2005.

Rowe, Erin K., «St. Teresa and Olivares: Patron Sainthood, Royal Favorites, and the Politics of Plurality in Seventeenth-Century Spain», The Sixteenth Century Journal, 37/3 (Kirksville, 2006a): 721-737.

Rowe, Erin K., «The Spanish Minerva: Imagining Teresa of Avila as Patron Saint in Seventeenth-Century Spain», The Catholic Historical Review, XCVII, 3 (Washington, 2006b): 416-438.

Rowe, Erin K., Saint and Nation: Santiago, Teresa of Avila, and Plural Identities in Early Modern Spain, Penn, State University Press, 2011.

Rucquoie, Adeline, «Clavijo: Saint Jacques Matamore», Compostelle. Cahiers d'Études, 10 (París, 2007): 48-58.

Saavedra, Pegerto, Vida cotidiana en la Galicia del Antiguo Régimen, Barcelona, Crítica, 1995.

Saborit, Pere, «Aspectos de la evolución de la religiosidad popular en el País Valenciano en época moderna», en María Jesús Buxó, Salvador Rodríguez Becerra y León Carlos Álvarez y Santaló (eds.), La religiosidad popular: Vida y muerte, Barcelona, Anthropos, 2003, vol. 1: 425-444.

Santos, Zulmira C. (coord.), Fontes para o estudo da santidade em Portugal na Epoca Moderna, Porto, Universidade de Porto, 2013.

Serrano Martín, Eliseo, El Pilar, la Historia y la tradición, Zaragoza, Editorial Mira, 2015.

Serrano Martín, Eliseo, «Santidad y patronazgo en el mundo hispánico de la Edad Moderna», Studia Historica. Historia Moderna, 40/1 (Salamanca, 2018): 75-123.

Serrao, Joaquim Veríssimo, História de Portugal. Governo dos Reis Espanhois (15801640), Lisboa, Editorial Verbo, 1979.

Serrao, Joaquim Veríssimo, História de Portugal. O século de Ouro: 1495-1580, Lisboa, Editorial Verbo, 1980.

Serrao, Joaquim Veríssimo, História de Portugal: A restauração e a monarquia absoluta (1640-1750), Lisboa, Editorial Verbo, 1982.

Sousa Macedo, Antonio de, Flores de España, excelencias de Portugal, Lisboa, Iorge Rodrigues impresor, 1631.

Stradling, Robert A., Felipe IV y el gobierno de España, 1621-1665, Madrid, Cátedra, 1989.

Strobel, Thomas, O sebastianismo: breve panorama de uma mitogenia nacional, Lisboa, Grin Publishing, 2001. 
Thompson, Irving A., «La cuestión de la autoridad en la controversia sobre el Patronato de Santa Teresa de Jesús», en Francisco José Aranda Pérez y José Damiâo Rodrigues, De Re publica Hispaniae, Madrid, Sílex, 2008: 293-320.

Valladares, Rafael, Portugal y la monarquía hispánica, 1580-1668, Madrid, Arco Libros, 2000.

Valladares, Rafael, Felipe IV y la restauración de Portugal, Málaga, Editorial Algazara, 2004.

Van Liere, Katherine Elliot, «Renaissance chroniclers and the apostolic origins of Christianity», en Katherine van Liere, Simon Ditchfield y Howard Louthan (eds.), Sacred History: Uses of the Christian Past in the Renaissance World, Oxford, Oxford University Press, 2012: 121-144.

Vivar, Francisco, Quevedo y su España imaginada, Madrid, Visor libros, 2002.

Webb, Diana, Patrons and defenders. The saints in the Italian city states, Londres, Tauris, 1996.

Wilson, Stephen, The means of naming, Londres, Routledge, 1998.

Recibido: 11/06/2019

Aceptado: 13/10/2020 